\title{
Mammary gland utilization of amino acids and energy metabolites differs when dairy cow rations are isoenergetically supplemented with protein and fat
}

\author{
K. Nichols, ${ }^{1,2 *}$ H. van Laar, ${ }^{3}$ A. Bannink, ${ }^{2}$ and J. Dijkstra ${ }^{1}$ \\ ${ }^{1}$ Animal Nutrition Group, Wageningen University and Research, PO Box 338, 6700 AH Wageningen, the Netherlands \\ ${ }^{2}$ Wageningen Livestock Research, Wageningen University and Research, PO Box 338, $6700 \mathrm{AH}$ Wageningen, the Netherlands \\ ${ }^{3}$ Trouw Nutrition R\&D, PO Box 220, 5830 AE Boxmeer, the Netherlands
}

\section{ABSTRACT}

Mammary gland utilization of AA and other metabolites in response to supplemental energy from protein $(\mathrm{PT})$ and supplemental energy from fat (FT) was tested in a $2 \times 2$ factorial arrangement using a randomized complete block design. Fifty-six Holstein-Friesian dairy cows were adapted during a $28-\mathrm{d}$ control period to a basal total mixed ration consisting of $34 \%$ grass silage, $33 \%$ corn silage, $5 \%$ grass hay, and $28 \%$ concentrate on a dry matter (DM) basis. Experimental rations were fed for $28 \mathrm{~d}$ immediately following the control period and consisted of (1) low protein, low fat (LP/LF), (2) high protein, low fat (HP/LF), (3) low protein, high fat $(\mathrm{LP} / \mathrm{HF})$, and (4) high protein, high fat $(\mathrm{HP} / \mathrm{HF})$. To obtain the high-protein (HP) and high-fat (HF) diets, intake of the basal ration was restricted and supplemented isoenergetically [net energy $(\mathrm{MJ} / \mathrm{d})$ basis] with $2.0 \mathrm{~kg} / \mathrm{d}$ rumen-protected protein (soybean + rapeseed, $50: 50$ mixture on a DM basis) and $0.68 \mathrm{~kg} / \mathrm{d}$ hydrogenated palm fatty acids on a DM basis. Arterial and venous blood samples were collected on d 28 of both periods. Isoenergetic supplements $(\mathrm{MJ} / \mathrm{d})$ of protein and fat independently and additively increased milk yield, PT increased protein yield, and FT increased fat yield. A PT $\times$ FT interaction affected arterial concentration of all essential AA (EAA) groups, where they increased in response to $\mathrm{PT}$ by a greater magnitude at the LF level (on average 35\%) compared with the HF level (on average 14\%). Mammary gland plasma flow was unaffected by PT or FT. Supplementation with PT tended to decrease mammary clearance of total EAA and decreased group 1 AA clearance by $19 \%$. In response to PT, mammary uptake of total EAA and group 2 AA increased 12 and 14\%, respectively, with significantly higher uptake of Arg, Ile, and Leu. Energy

Received May 29, 2018.

Accepted October 10, 2018.

*Corresponding author: kelly.nichols@wur.nl from fat had no effect on mammary clearance or uptake of any AA group. The mammary gland uptake:milk protein output ratio was not affected by FT, whereas PT increased this ratio for EAA and group 2 AA. Arterial plasma insulin concentration decreased in response to FT, in particular on the $\mathrm{HP} / \mathrm{HF}$ diet, as indicated by a PT $\times$ FT interaction. Arterial concentrations of nonesterified fatty acids, triacylglycerol, and long-chain fatty acids increased in response to FT, and concentrations of $\beta$-hydroxybutyrate and acetate decreased in response to FT only at the HP level. Mammary clearance and uptake of triacylglycerol and long-chain fatty acids increased in response to FT. Energy from PT and FT increased lactose yield despite no change in arterial glucose concentration or mammary glucose uptake. Mammary-sequestered glucose with PT or FT was used in the same amount for lactose synthesis, and a positive net mammary glucose balance was found across all treatments. Results presented here illustrate metabolic flexibility of the mammary gland in its use of aminogenic versus lipogenic substrates for milk synthesis.

Key words: amino acid, hydrogenated palm fatty acid, protein synthesis, lactose synthesis, mammary gland

\section{INTRODUCTION}

Lactating mammary glands have an obligatory requirement for glucose as a substrate to synthesize lactose. Lactose synthesis represents the major fate of glucose metabolism in mammary epithelial cells, and glucose oxidation facilitates the synthesis of other milk components such as fatty acids (FA) and protein (Mepham, 1987; Xiao and Cant, 2005). A relationship exists between MP supply and lactose yield independent of glucose supply, where infusions of casein or AA mixtures increase both milk protein and lactose yield (Galindo et al., 2011; Nichols et al., 2016). This relationship suggests that AA supplementation has an effect on whole-body energy partitioning and mammary gland metabolism (Lemosquet et al., 2009a; Lapierre et al., 
2010). Rumen-protected protein sources are fed with the objective of increasing AA availability for absorption and mammary gland extraction at first pass, but because milk synthesis is an energy-demanding process, AA may be oxidized if the concomitant supply of energy for productive purposes is lacking. Alternatively, supply of non-AA energy precursors can optimize the use of available AA for milk protein synthesis and alter the kinetics of mammary AA uptake (Raggio et al., 2006; Rius et al., 2010a). Infusions of propionate, starch, and glucose into the digestive tract, with and without casein or AA infusion, have been studied extensively (Lemosquet et al., 2009a; Rius et al., 2010b; Nichols et al., 2016), but few studies exist examining mammary gland kinetics in response to postruminal fat supplementation.

Lactose yield from dairy cows on lipogenic diets is equal to or higher than that with glucogenic diets in some studies (Hammon et al., 2008; Lohrenz et al., 2010) but not in all (Boerman et al., 2015; van Hoeij et al., 2017). Long-chain FA (LCFA) do not directly contribute to glucose precursors necessary for lactose synthesis, but increased mammary extraction of LCFA can decrease de novo FA synthesis by the gland (Grummer and Carroll, 1991; Chilliard, 1993; Hammon et al., 2008) which may reduce glucose requirements for oxidative catabolism and increase supply of energy for lactose and protein synthesis. Cant et al. (1993a) fed a mix of saturated and unsaturated fats and observed increased mammary uptake of triacylglycerides (TAG) and output of LCFA into milk, higher lactose yield, and increased mammary glucose utilization for lactose. Previous work has quantified mammary AA use in response to largely unsaturated fat sources (Casper and Schingoethe, 1989; Casper et al., 1990; Cant et al., 1993b), but there is a paucity of recent data characterizing AA responses to rumen-inert fat supplements.

Intramammary metabolism must be flexible to derive substrates for the regulation of milk volume and composition based on supply of aminogenic, lipogenic, or glucogenic precursors. In an experiment to test this concept (Nichols et al., 2018), isoenergetic levels of protein or fat supplementation increased total milk, lactose, protein (tendency with fat supplementation), and fat yield (tendency with protein supplementation). The increase in milk fat yield with fat supplementation was associated with a shift toward incorporation of LCFA and decreased de novo FA synthesis. The aim of the present work was to investigate metabolite utilization by the mammary gland underlying these observed milk production responses. The current study used a practical and relatively large-scale approach to measure mammary gland metabolism. We expected AA from protein to support mammary protein synthesis and, if acting as a glucogenic substrate, to yield glucose in support of lactose synthesis. This study is also unique in its characterization of mammary gland kinetics with fat supplementation at low and high MP levels. We hypothesized that, compared with low-fat diets, energy from fat would stimulate mammary AA sequestration or reduce AA catabolism in support of milk protein synthesis and increase glucose sequestration in support of lactose synthesis.

\section{MATERIALS AND METHODS}

\section{Experimental Design}

Experimental procedures were approved by the Animal Care and Use Committee for Nutreco Nederland B.V. (Amersfoort, the Netherlands) and conducted under the Dutch Law on Animal Experiments. The experimental design, animal housing, diets, and feed chemical analyses have been described in detail by Nichols et al. (2018). Briefly, 56 Holstein-Friesian cows (20 primiparous, $138 \pm 64$ DIM; 36 multiparous, $3.7 \pm 1.8$ lactations, $181 \pm 93$ DIM) were used in a randomized complete block design where supplemental energy from protein $(\mathbf{P T})$ or supplemental energy from fat $(\mathbf{F T})$ was tested in a factorial arrangement over 2 successive periods (control and experimental), each consisting of $21 \mathrm{~d}$ of diet adaptation and $7 \mathrm{~d}$ of data collection. A basal diet was fed as a TMR during the control period, consisting of $34 \%$ grass silage, $33 \%$ corn silage, $5 \%$ grass hay, and $28 \%$ concentrate on a DM basis, and was designed to meet $\mathrm{NE}_{\mathrm{L}}$ and $\mathrm{MP}$ requirements for cows of $650 \mathrm{~kg}$ of BW consuming $22 \mathrm{~kg}$ of DM/d producing $30 \mathrm{~kg}$ of milk/d containing $45 \mathrm{~g} / \mathrm{kg}$ fat and 35 $\mathrm{g} / \mathrm{kg}$ protein. Cows were blocked by parity, DIM, and DMI of the final $7 \mathrm{~d}$ of the control period and within blocks were randomly assigned to 1 of 4 diets for the experimental period: (1) low protein, low fat (LP/LF; 95\% MP, 95\% NE $\mathrm{NE}_{\mathrm{L}}$ ), (2) high protein, low fat (HP/LF; $131 \% \mathrm{MP}, 107 \% \mathrm{NE}_{\mathrm{L}}$ ), (3) low protein, high fat (LP/ HF; $95 \% \mathrm{MP}, 107 \% \mathrm{NE}_{\mathrm{L}}$ ), and (4) high protein, high fat $\left(\mathbf{H P} / \mathbf{H F} ; 131 \% \mathrm{MP}, 119 \% \mathrm{NE}_{\mathrm{L}}\right)$, where MP and $\mathrm{NE}_{\mathrm{L}}$ are expressed relative to animal requirements in the control period. For all treatments, basal diet intake for individual cows was restricted to $95 \%$ of their ad libitum intake recorded during the control period. To obtain the high protein (HP) and high fat (HF) diets, a 2.0-kg 50:50 mixture (DM basis) of rumen-protected (RP) soybean meal and rapeseed meal (both rumen protected by xylose treatment; SoyPass + RaPass; Borregaard LignoTech, Sarpsborg, Norway) and 0.68 $\mathrm{kg}$ of rumen-inert hydrogenated LCFA (85\% free FA and 15\% triglycerides; $50 \% \mathrm{C} 16: 0$ and $47 \%$ C18:0; Hidropalm; Norel, Madrid, Spain) on a DM basis were 
Table 1. Formulated TMR component intake, calculated chemical composition, and DMI during the control period and during the experimental period for the basal diet (LP/LF) or diets supplemented with energy from protein $(\mathrm{HP} / \mathrm{LF})$, fat $(\mathrm{LP} / \mathrm{HF})$, or protein and fat $(\mathrm{HP} / \mathrm{HF})^{1,2}$

\begin{tabular}{|c|c|c|c|c|c|}
\hline Item & Control & $\mathrm{LP} / \mathrm{LF}$ & $\mathrm{HP} / \mathrm{LF}$ & $\mathrm{LP} / \mathrm{HF}$ & $\mathrm{HP} / \mathrm{HF}$ \\
\hline \multicolumn{6}{|l|}{ Ingredient, $\mathrm{kg}$ of $\mathrm{DM} / \mathrm{d}$} \\
\hline Grass silage & 7.1 & 6.7 & 6.7 & 6.7 & 6.7 \\
\hline Corn silage & 6.9 & 6.5 & 6.5 & 6.5 & 6.5 \\
\hline Grass hay & 1.00 & 0.98 & 0.98 & 0.98 & 0.98 \\
\hline Concentrate $^{3}$ & 5.8 & 5.5 & 5.5 & 5.5 & 5.5 \\
\hline SoyPass + RaPass ${ }^{4}$ & - & - & 2.0 & - & 2.0 \\
\hline Hidropalm ${ }^{5}$ & - & - & - & 0.68 & 0.68 \\
\hline Total predicted DMI, $\mathrm{kg} / \mathrm{d}$ & 20.8 & 19.7 & 21.7 & 20.5 & 22.5 \\
\hline Observed DMI, $\mathrm{kg} / \mathrm{d}$ & 20.1 & 19.7 & 21.4 & 19.5 & 21.4 \\
\hline \multicolumn{6}{|l|}{$\mathrm{NE}_{\mathrm{L}}{ }^{6} \mathrm{MJ} / \mathrm{kg}$ of $\mathrm{DM}$} \\
\hline Concentrate & 7.22 & 7.19 & 7.57 & 8.95 & 8.63 \\
\hline TMR & 6.68 & 6.68 & 6.85 & 7.23 & 7.26 \\
\hline \multicolumn{6}{|l|}{$\mathrm{DVE}^{7}$} \\
\hline Concentrate & 152 & 152 & 205 & 131 & 178 \\
\hline TMR & 87 & 87 & 111 & 83 & 105 \\
\hline
\end{tabular}

${ }^{1}$ Values for TMR were calculated based on ration composition and calculated values obtained for roughages and concentrate. Calculated values for grass silage and corn silage were obtained from near-infrared spectroscopy analysis (Eurofins Agro, Wageningen, the Netherlands), and values for grass hay were obtained from CVB (2008). Concentrate values including SoyPass, RaPass, and Hidropalm were estimated from raw material composition from CVB (2008).

${ }^{2} \mathrm{LP} / \mathrm{LF}=$ basal TMR fed at $95 \%$ of control ad libitum intake with no protein or fat supplement; $\mathrm{HP} / \mathrm{LF}=$ TMR fed at $95 \%$ of control ad libitum intake supplemented daily with $2.0 \mathrm{~kg}$ of SoyPass + RaPass (Borregaard LignoTech, Sarpsborg, Norway) on a DM basis; LP/HF = TMR fed at 95\% of control ad libitum intake supplemented daily with $0.68 \mathrm{~kg}$ of Hidropalm (Norel Animal Nutrition, Madrid, Spain) on a DM basis; HP $/ \mathrm{HF}=$ TMR fed at $95 \%$ of control ad libitum intake supplemented daily with $2.0 \mathrm{~kg}$ of SoyPass + RaPass and 0.68 $\mathrm{kg}$ of Hidropalm on a DM basis.

${ }^{3}$ Portion of concentrate excluding rumen-protected protein and hydrogenated palm fatty acid supplements.

${ }^{4}$ A 50:50 mix (DM basis) of SoyPass (xylose-treated rumen-protected soybean meal) and RaPass (xylosetreated rumen-protected rapeseed meal) manufactured by Borregaard LignoTech (Sarpsborg, Norway).

${ }^{5}$ Hidropalm (hydrogenated palm fatty acids; $85 \%$ free fatty acids and $15 \%$ triglycerides; $50 \%$ C16:0 and $47 \%$ C18:0) manufactured by Norel Animal Nutrition (Madrid, Spain).

${ }^{6}$ Calculated with the VEM system (CVB, 2008).

${ }^{7}$ Intestinal digestible protein (CVB, 2008).

supplemented into the concentrate portion of each basal TMR such that additional daily intake of $\mathrm{MP}$ and $\mathrm{NE}_{\mathrm{L}}$ arose from the supplement addition. Therefore, differences in DMI between each diet were created by design (Table 1) to allow isoenergetic intake of protein and fat with HP and HF. Ingredient and chemical compositions of the control and experimental diets are presented in Table 1 . The TMR were mixed and distributed once daily at $1000 \mathrm{~h}$ via electronic intake boxes (Insentec, Marknesse, the Netherlands) that controlled and recorded intake of individual animals. Cows were milked twice daily at 530 and $1630 \mathrm{~h}$, and milk production was recorded electronically.

\section{Milk and Blood Collection and Analysis}

Milk sampling for daily composition analysis is described by Nichols et al. (2018). For analyses of mammary gland metabolite uptake, milk samples were collected from individual cows during the final week of each period in the afternoon milking on d 25 and 27, pooled into a weekly afternoon sample by individual cow, stored at $4^{\circ} \mathrm{C}$, and analyzed within $3 \mathrm{~d}$. On d 28 of each period at $0800,1000,1200$, and $1400 \mathrm{~h}$, blood samples were collected by venipuncture into $10-\mathrm{mL}$ sodium heparin and potassium EDTA Vacutainers (Becton Dickinson, Franklin Lakes, NJ) concurrently from the coccygeal vessels, where arteriovenous (AV) differences across the tail are assumed to be negligible, thus representing mammary arterial supply (Emery et al., 1965), and from the subcutaneous abdominal vein of each cow. Samples were collected from the left and right subcutaneous abdominal veins, alternating at each time point, to account for differences between sides and to avoid oversampling a particular area. Collection tubes were immediately placed in ice and centrifuged at 3,000 $\times g$ for $15 \mathrm{~min}$ at $4^{\circ} \mathrm{C}$. Plasma was transferred into polypropylene tubes and frozen at $-20^{\circ} \mathrm{C}$ until analysis.

Pooled afternoon milk samples were analyzed weekly for fat, CP, lactose, and milk urea by mid-infrared spectroscopy (ISO method 9622; ISO, 2013; Qlip NV, Zutphen, the Netherlands). Arterial and venous plasma 
samples were pooled over time and by sampling site for each cow by period and analyzed for glucose, BHB, nonesterified FA (NEFA), TAG, and acetate according to the methods of Weekes et al. (2006) and for urea (kit no. MAK006; Sigma Chemical Co., Oakville, ON, Canada). Long-chain FA concentrations were calculated on a molar basis as $3 \times \mathrm{TAG}+\mathrm{NEFA}$. Immunoassay was used for analysis of growth hormone (kit no. CSB-E13443B; Cusabio, Wuhan, China), IGF-1 (kit no. CSB-E08893b; Cusabio), leptin (kit no. CSBE06771b; Cusabio), and insulin (kit no. 90060; Crystal Chem Inc., Downers Grove, IL). Amino acid concentrations in plasma samples collected at 1000, 1200, and $1400 \mathrm{~h}$ were analyzed using ultra-performance liquid chromatography in conjunction with Empower Chromatography Data software (Waters Corp., Milford, MA) according to the protocol described by Boogers et al. (2008).

\section{Calculations and Statistical Analysis}

Plasma AA concentrations were averaged over the 3 analyzed sampling times. Milk CP was assumed to consist of $94.5 \%$ true protein (DePeters and Ferguson, 1992). All following calculations were based on this estimate of true protein yield. Mammary plasma flow (MPF) across the whole udder was estimated according to the Fick principle using Phe and Tyr as internal markers (Cant et al., 1993b), where MPF (L/h) $=[$ milk Phe + Tyr output $(\mu \mathrm{mol} / \mathrm{h})] /[$ AV Phe + Tyr difference $(\mu \mathrm{mol} / \mathrm{L})]$, with an allowance for $3.37 \%$ contribution from blood-derived proteins (Lapierre et al., 2012). Milk output of Phe + Tyr was estimated from the afternoon milk protein yield using the mean Phe and Tyr contents reported by Mepham (1987) and Lapierre et al. (2012). Mammary clearances of metabolites were calculated from the model of Hanigan et al. (1998), where clearance $(\mathrm{L} / \mathrm{h})=(\mathrm{AV}$ difference $\times \mathrm{MPF}) /$ venous concentration. Uptakes $(\mathrm{mmol} / \mathrm{h})$ of metabolites across the mammary glands were calculated as the product of their plasma AV differences and MPF. Positive AV differences and uptakes indicate metabolite removal from plasma, whereas negative values indicate net metabolite release from the mammary glands. Mammary gland nutrient balances were calculated using mean milk protein AA composition reported by Mepham (1987) and Lapierre et al. (2012) for AA uptake:output ratios (U:O) and according to estimations of Dijkstra et al. (1996) for glucose, 2C compounds (acetate and BHB), and LCFA. Of C16 FA in milk, 50\% were assumed to be synthesized de novo from $2 \mathrm{C}$ compounds and $50 \%$ were assumed to be sequestered as preformed FA. The molecular weight of $\mathrm{FA} \geq 16 \mathrm{C}$ in blood was calculated according to their molecular weight in milk, and the $50 \%$ contribution of C16 was applied.

Variances in milk and milk component production, plasma constituent concentrations, AV differences, and mammary clearances and uptakes were analyzed using the MIXED procedure of SAS (SAS Institute Inc., Cary, NC) with level of protein and fat and their interaction as fixed effects and parameters measured during the control period used as covariates according to the following model:

$$
\begin{aligned}
\mathrm{Y}_{\mathrm{ijkl}}=\mu & +\beta \times \mu_{1}+\text { block }_{\mathrm{i}}+\mathrm{PT}_{\mathrm{j}}+\mathrm{FT}_{\mathrm{k}} \\
& +(\mathrm{PT} \times \mathrm{FT})_{\mathrm{jk}}+\varepsilon_{\mathrm{ijk} l},
\end{aligned}
$$

where $Y_{i j k l}=$ observed trait, $\mu=$ overall mean, $\beta=$ control covariate parameter, $\mu_{1}=$ observed trait in the control period of cow 1 , block $\mathrm{k}_{\mathrm{i}}=$ random block effect (i $=1$ to 14$), \mathrm{PT}_{\mathrm{j}}=$ fixed protein effect $(\mathrm{j}=1$ to 2$), \mathrm{FT}_{\mathrm{k}}$ $=$ fixed fat effect $(\mathrm{k}=1$ to 2$),(\mathrm{PT} \times \mathrm{FT})_{\mathrm{jk}}=$ interaction between fixed PT and FT effects, and $\varepsilon_{\mathrm{ijkl}}=$ residual random error term. Differences were considered significant at $P \leq 0.05$ and tendencies at $0.05<P \leq$ 0.10 . Multiple comparisons between treatment means were made using the Tukey-Kramer method when a PT $\times$ FT interaction was detected at $P \leq 0.10$.

\section{RESULTS}

\section{Milk Production}

Daily lactation performance was presented by Nichols et al. (2018). The present paper reports milk production on an hourly basis (Table 2). Total milk yield and lactose yield increased in response to PT $(P \leq 0.01)$ and FT $(P \leq 0.03)$. Milk protein yield increased in response to $\mathrm{PT}(P<0.01)$ and tended to increase in response to FT $(P=0.05)$. Milk fat yield increased in response to $\mathrm{FT}(P<0.01)$ and tended to increase in response to $\mathrm{PT}(P=0.10)$. Milk protein content increased in response to PT $(P<0.01)$, fat content increased in response to FT $(P=0.02)$, and lactose content was unaffected by PT or FT. Milk urea content increased in response to PT $(P<0.01)$, but the effect tended to be greater at the LF level $(\mathrm{PT} \times \mathrm{FT}$ interaction, $P=0.06)$.

\section{Arterial AA Concentrations, Mammary Plasma Flow, and AA Kinetics}

Arterial plasma AA concentrations of total EAA, group $1 \mathrm{AA}$, and group $2 \mathrm{AA}$ were affected by a $\mathrm{PT} \times$ FT interaction where the increase in response to PT was greater at the LF level compared with the HF level 
Table 2. Milk and component production of lactating dairy cows fed the basal diet (LP/LF) or diets supplemented with energy from protein $(\mathrm{HP} / \mathrm{LF})$, fat $(\mathrm{LP} / \mathrm{HF})$, or protein and fat $(\mathrm{HP} / \mathrm{HF})^{1}$

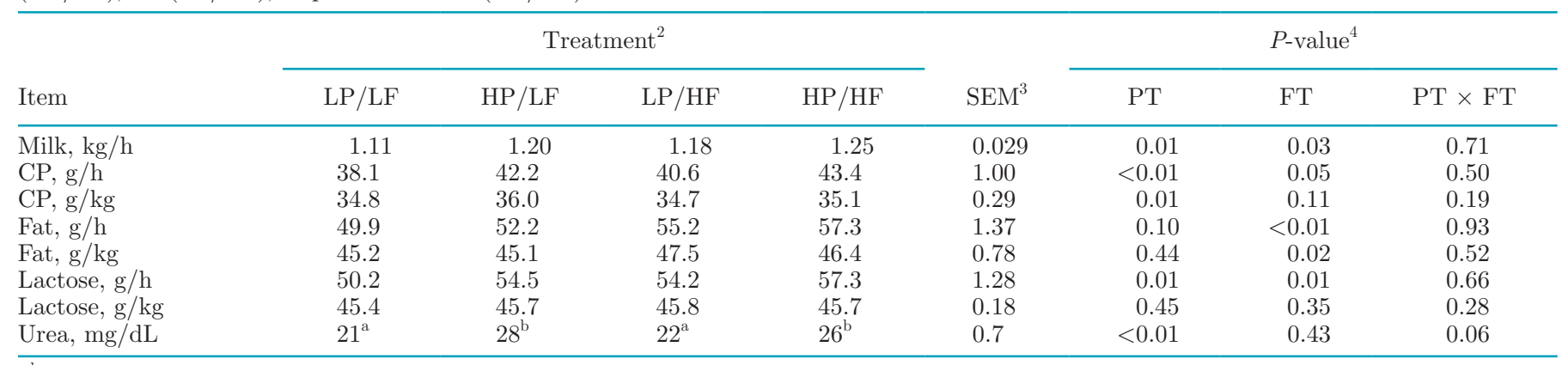

a,b Means within a row with no common superscripts differ $(P<0.05)$.

${ }^{1}$ Data are LSM from the final week of the experimental period using data from the final week of the control period as covariates for each parameter.

${ }^{2} \mathrm{LP} / \mathrm{LF}=$ basal TMR fed at $95 \%$ of control ad libitum intake with no protein or fat supplement; HP $/ \mathrm{LF}=\mathrm{TMR}$ fed at $95 \%$ of control ad libitum intake supplemented daily with $2.0 \mathrm{~kg}$ of SoyPass + RaPass (Borregaard LignoTech, Sarpsborg, Norway) on a DM basis; LP/HF = TMR fed at $95 \%$ of control ad libitum intake supplemented daily with $0.68 \mathrm{~kg}$ of Hidropalm (Norel Animal Nutrition, Madrid, Spain) on a DM basis; HP/HF $=$ TMR fed at $95 \%$ of control ad libitum intake supplemented daily with $2.0 \mathrm{~kg}$ of SoyPass + RaPass and $0.68 \mathrm{~kg}$ of Hidropalm on a DM basis. ${ }^{3} \mathrm{n}=14$.

${ }^{4} \mathrm{PT}=$ effect of energy from protein; FT $=$ effect of energy from fat.

$(P \leq 0.03 ;$ Table 3$)$. The increase in response to PT was greater at the LF level compared with the HF level for His, Ile, Leu, and Val $(P \leq 0.05)$ and tended to be greater for Lys and Phe $(P \leq 0.07)$. Concentrations of all other individual EAA were unaffected by FT but increased in response to PT $(P \leq 0.04)$ with the exception of Met, which was unaffected. Concentration of total NEAA was unaffected by PT or FT. Individually, Pro and Tyr increased $(P<0.01)$ and Gln decreased $(P$ $=0.02)$ in response to $\mathrm{PT}$, and Gly tended to increase in response to $\mathrm{FT}(P=0.09)$.

Arteriovenous differences of total EAA, group $1 \mathrm{AA}$, and group 2 AA were affected by a PT $\times$ FT interaction where the increase in response to $\mathrm{PT}$ was greater at the LF level compared with the HF level $(P \leq 0.02$; Table 4). Individually, the increase in AV difference in response to $\mathrm{PT}$ was greater at the $\mathrm{LF}$ level compared with the HF level for His, Ile, Leu, Lys, and Thr $(P \leq$ $0.05)$ and tended to be greater for Phe and $\operatorname{Trp}(P \leq$ $0.08)$. Arteriovenous differences for all individual EAA were unaffected by FT, and AV difference of Arg and Val increased in response to PT $(P \leq 0.01)$. Arteriovenous difference for total NEAA was affected by a PT $\times$ FT interaction where the lowest AV difference was reached at $\mathrm{LP} / \mathrm{LF}$ and $\mathrm{HP} / \mathrm{HF}$ and the highest was reached at $\mathrm{HP} / \mathrm{LF}$ and $\mathrm{LP} / \mathrm{HF}(P=0.02)$. Individually, AV difference of Asn and of Gln increased $(P<$ $0.01)$ and that of Tyr tended to increase $(P=0.06)$ in response to $\mathrm{PT}$ to a greater extent at the $\mathrm{LF}$ level than at the HF level, and Gly AV difference tended to reach the lowest $\mathrm{AV}$ difference at $\mathrm{LP} / \mathrm{LF}$ and $\mathrm{HP} / \mathrm{HF}$ and the highest $\mathrm{AV}$ difference at $\mathrm{HP} / \mathrm{LF}$ and $\mathrm{LP} / \mathrm{HF}(P=$
0.08). The AV difference of Asp tended to increase ( $P$ $=0.09)$ in response to PT, and the AV difference of Glu decreased in response to PT and FT $(P=0.02)$.

Mammary plasma flow and AA clearance rates are presented in Table 5. Mammary plasma flow tended to be affected by a PT $\times$ FT interaction $(P=0.07)$, where the highest plasma flow was observed at LP/LF. Mammary clearance of total EAA tended to decrease in response to $\mathrm{PT}(P=0.06)$ and was unaffected by FT. Clearance of group 1 AA decreased in response to PT $(P<0.01)$, whereas group $2 \mathrm{AA}$ clearance was unaffected by PT or FT. Individually, clearance of His, Leu, and Phe decreased (all $P<0.01$ ) in response to PT. Clearance of Met decreased in response to FT $(P$ $=0.03$. Mammary clearance of total NEAA tended to be affected by a PT $\times$ FT interaction $(P=0.07)$. In response to $\mathrm{PT}$, Glu clearance tended to decrease more at the HF level $(P=0.08)$, Gln clearance tended to increase more at the LF level $(P=0.08)$, and Ala clearance tended to decrease $(P=0.06)$. Clearance of Ser increased in response to FT $(P=0.01)$.

Mammary gland net uptake of total EAA increased in response to $\mathrm{PT}(P=0.03)$ and was unaffected by $\mathrm{FT}$ (Table 6). Uptake of group $1 \mathrm{AA}$ was unaffected by PT or FT, but uptake of group $2 \mathrm{AA}$ increased in response to PT $(P=0.02)$. Individually, uptakes of Arg, Ile, and Leu increased $(P \leq 0.04)$ and uptake of Val tended to increase $(P=0.07)$ in response to PT. Uptakes of individual EAA were not affected by FT. Mammary net uptake of total NEAA tended to be affected by a $\mathrm{PT} \times \mathrm{FT}$ interaction $(P=0.08)$. Individually, a PT $\times$ FT interaction affected uptake of Asn $(P=0.03)$, 
indicating an increase in response to PT at the $\mathrm{LF}$ level but no response at the $\mathrm{HF}$ level, and tended to affect uptake of Gln and Gly $(P=0.06)$, where they reached the lowest uptake at $\mathrm{LP} / \mathrm{LF}$ and $\mathrm{HP} / \mathrm{HF}$ and the highest uptake at $\mathrm{HP} / \mathrm{LF}$ and $\mathrm{LP} / \mathrm{HF}$. In response to $\mathrm{PT}$, uptake of Tyr increased $(P=0.05)$ and uptakes of Ala and Glu decreased $(P \leq 0.04)$. Uptake of Ser increased in response to $\mathrm{FT}(P=0.03)$.

The mammary gland U:O of total EAA and group 2 AA increased in response to PT $(P=0.04$; Table 7). This ratio for the group $1 \mathrm{AA}$ was unaffected by $\mathrm{PT}$ or FT. Individually, in response to PT, the U:O of Leu tended to be affected more at the LF level (PT $\times$ FT interaction; $P=0.06)$. The $\mathrm{U}: \mathrm{O}$ of Ile and Val increased in response to PT $(P \leq 0.05)$, and the $\mathrm{U}: \mathrm{O}$ of Trp tended to decrease $(P=0.10)$. A PT $\times$ FT interaction affected NEAA $\mathrm{U}: \mathrm{O}(P=0.06)$, which numerically decreased upon increasing $\mathrm{PT}$ at the $\mathrm{HF}$ level but not at the LF level. Individually, the U:O of Asn was affected by a $\mathrm{PT} \times \mathrm{FT}$ interaction where the lowest values were achieved on $\mathrm{LP} / \mathrm{LF}$ and $\mathrm{HP} / \mathrm{HF}(P$ $<0.01)$; a similar tendency $(P \leq 0.08)$ was observed for Gln and Gly. The U:O of Ala and Glu decreased in response to $\mathrm{PT}(P \leq 0.01)$, and the $\mathrm{U}: \mathrm{O}$ of Glu tended to decrease $(P=0.10)$ and Ser tended to increase $(P=$ $0.07)$ in response to FT.

\section{Other Metabolites and Hormones: Arterial Concentrations and Kinetics}

Arterial plasma glucose concentration was unaffected by PT or FT (Table 8$)$. A PT $\times$ FT interaction affected BHB and acetate concentrations $(P \leq 0.04)$, where they increased in response to PT, but only at the LF level.

Table 3. Arterial plasma concentrations $(\mu M)$ of AA in lactating dairy cows fed the basal diet (LP/LF) or diets supplemented with energy from protein $(\mathrm{HP} / \mathrm{LF})$, fat $(\mathrm{LP} / \mathrm{HF})$, or protein and fat $(\mathrm{HP} / \mathrm{HF})^{1}$

\begin{tabular}{|c|c|c|c|c|c|c|c|c|}
\hline Item & \multicolumn{4}{|c|}{ Treatment $^{2}$} & $\mathrm{SEM}^{3}$ & \multicolumn{3}{|c|}{$P$-value ${ }^{4}$} \\
\hline Ile & $139^{\mathrm{a}}$ & $168^{\mathrm{b}}$ & $146^{\mathrm{ab}}$ & $150^{\mathrm{ab}}$ & 5.9 & 0.01 & 0.35 & 0.05 \\
\hline Leu & $99^{\mathrm{a}}$ & $158^{\mathrm{b}}$ & $104^{\mathrm{a}}$ & $139^{\mathrm{b}}$ & 5.1 & $<0.01$ & 0.17 & 0.03 \\
\hline Lys & $78^{\mathrm{a}}$ & $93^{\mathrm{b}}$ & $84^{\mathrm{ab}}$ & $85^{\mathrm{ab}}$ & 3.6 & 0.04 & 0.77 & 0.06 \\
\hline Thr & 94 & 105 & 94 & 101 & 4.1 & 0.04 & 0.76 & 0.64 \\
\hline Trp & 42 & 48 & 44 & 45 & 1.5 & 0.03 & 0.70 & 0.14 \\
\hline Val & $217^{\mathrm{a}}$ & $310^{\mathrm{b}}$ & $231^{\mathrm{a}}$ & $284^{\mathrm{b}}$ & 8.1 & $<0.01$ & 0.49 & 0.02 \\
\hline Ala & 207 & 202 & 220 & 202 & 7.5 & 0.11 & 0.35 & 0.42 \\
\hline Asn & 71 & 84 & 77 & 77 & 4.2 & 0.15 & 0.96 & 0.17 \\
\hline Asp & 6.3 & 7.6 & 6.2 & 6.8 & 0.55 & 0.12 & 0.42 & 0.54 \\
\hline Gln & 106 & 96 & 104 & 95 & 3.9 & 0.02 & 0.65 & 0.88 \\
\hline $\mathrm{EAA}^{5}$ & $817^{\mathrm{a}}$ & $1,109^{\mathrm{b}}$ & $867^{\mathrm{ac}}$ & $989^{\mathrm{bc}}$ & 33.0 & $<0.01$ & 0.30 & 0.02 \\
\hline Group $1^{6}$ & $169^{\mathrm{a}}$ & $227^{\mathrm{b}}$ & $178^{\mathrm{a}}$ & $205^{\mathrm{b}}$ & 6.3 & $<0.01$ & 0.30 & 0.02 \\
\hline Group $2^{7}$ & $696^{\mathrm{a}}$ & $941^{\mathrm{b}}$ & $738^{\mathrm{ac}}$ & $838^{\mathrm{bc}}$ & 30.5 & $<0.01$ & 0.32 & 0.03 \\
\hline NEAA $^{8}$ & 965 & 966 & 992 & 973 & 28.8 & 0.75 & 0.56 & 0.75 \\
\hline $\mathrm{TAA}^{9}$ & $1,777^{\mathrm{a}}$ & $2,084^{\mathrm{b}}$ & $1,860^{\mathrm{a}}$ & $1,956^{\mathrm{ab}}$ & 56.0 & $<0.01$ & 0.68 & 0.08 \\
\hline
\end{tabular}

${ }^{a-c}$ Means within a row with no common superscripts differ $(P<0.05)$.

${ }^{1}$ Data are LSM from d 28 of the experimental period where measurements on d 28 of the control period are used as covariates.

${ }^{2} \mathrm{LP} / \mathrm{LF}=$ basal TMR fed at $95 \%$ of control ad libitum intake with no protein or fat supplement; HP/LF $=$ TMR fed at $95 \%$ of control ad libitum intake supplemented daily with $2.0 \mathrm{~kg}$ of SoyPass + RaPass (Borregaard LignoTech, Sarpsborg, Norway) on a DM basis; LP/HF = TMR fed at $95 \%$ of control ad libitum intake supplemented daily with $0.68 \mathrm{~kg}$ of Hidropalm (Norel Animal Nutrition, Madrid, Spain) on a DM basis; HP/HF $=$ TMR fed at $95 \%$ of control ad libitum intake supplemented daily with $2.0 \mathrm{~kg}$ of SoyPass + RaPass and $0.68 \mathrm{~kg}$ of Hidropalm on a DM basis. ${ }^{3} \mathrm{n}=14$

${ }^{4} \mathrm{PT}=$ effect of energy from protein; FT $=$ effect of energy from fat.

${ }^{5} \mathrm{EAA}=$ Arg, His, Ile, Leu, Lys, Met, Phe, Thr, Trp, Val.

${ }^{6}$ Group 1 = His, Met, Phe + Tyr, Trp.

${ }^{7}$ Group 2 = Arg, Ile, Leu, Lys, Thr, Val.

${ }^{8}$ NEAA = Ala, Asn, Asp, Gln, Glu, Gly, Pro, Ser, Tyr.

${ }^{9}$ Total $\mathrm{AA}=\mathrm{EAA}+\mathrm{NEAA}$. 
Concentrations of NEFA, TAG, and LCFA increased in response to FT $(P<0.01)$ and were unaffected by $\mathrm{PT}$. Urea concentration increased in response to PT $(P<$ 0.01 ) and was unaffected by FT. All hormone concentrations were unaffected by PT or FT except insulin, which decreased in response to FT but only at the HP level $(\mathrm{PT} \times \mathrm{FT}$ interaction, $P<0.01)$.

Mammary AV difference, clearance, and uptake of glucose were unaffected by PT or FT (Table 9). A PT $\times$ FT interaction affected AV difference of BHB $(P=$ $0.03)$ and tended to affect the AV difference of acetate $(P=0.08)$, where the lowest AV difference was reached at $\mathrm{LP} / \mathrm{LF}$ and $\mathrm{HP} / \mathrm{HF}$ and the highest $\mathrm{AV}$ difference was reached at $\mathrm{HP} / \mathrm{LF}$ and LP/HF. Mammary AV difference, clearance, and uptake of NEFA were unaffected by PT or FT. Mammary AV difference $(P \leq 0.01)$, clearance $(P \leq 0.05)$, and uptake $(P<0.01)$ of TAG and LCFA increased in response to FT. Arteriovenous difference, clearance, and uptake of LCFA tended to decrease $(P \leq 0.09)$ in response to PT.

In response to FT, calculated glucose output as milk lactose tended to increase $(P=0.09$; Table 10) and glucose required for fat synthesis increased $(P=0.04)$, whereas PT did not affect these variables. Glucose uptake not required for lactose and fat synthesis was not affected by PT or FT. Milk output of $2 \mathrm{C}$ compounds increased in response to PT $(P=0.01)$, and output of LCFA increased in response to FT $(P<0.01)$. Calculated $2 \mathrm{C}$ balance was not affected by PT or FT. Longchain FA uptake did not cover requirements for LCFA output on any treatment and became more negative in response to $\mathrm{PT}(P=0.01)$.

Table 4. Mammary gland arteriovenous differences $(\mu M)$ of AA in lactating dairy cows fed the basal diet (LP/LF) or diets supplemented with energy from protein $(\mathrm{HP} / \mathrm{LF})$, fat $(\mathrm{LP} / \mathrm{HF})$, or from protein and fat $(\mathrm{HP} / \mathrm{HF})^{1}$

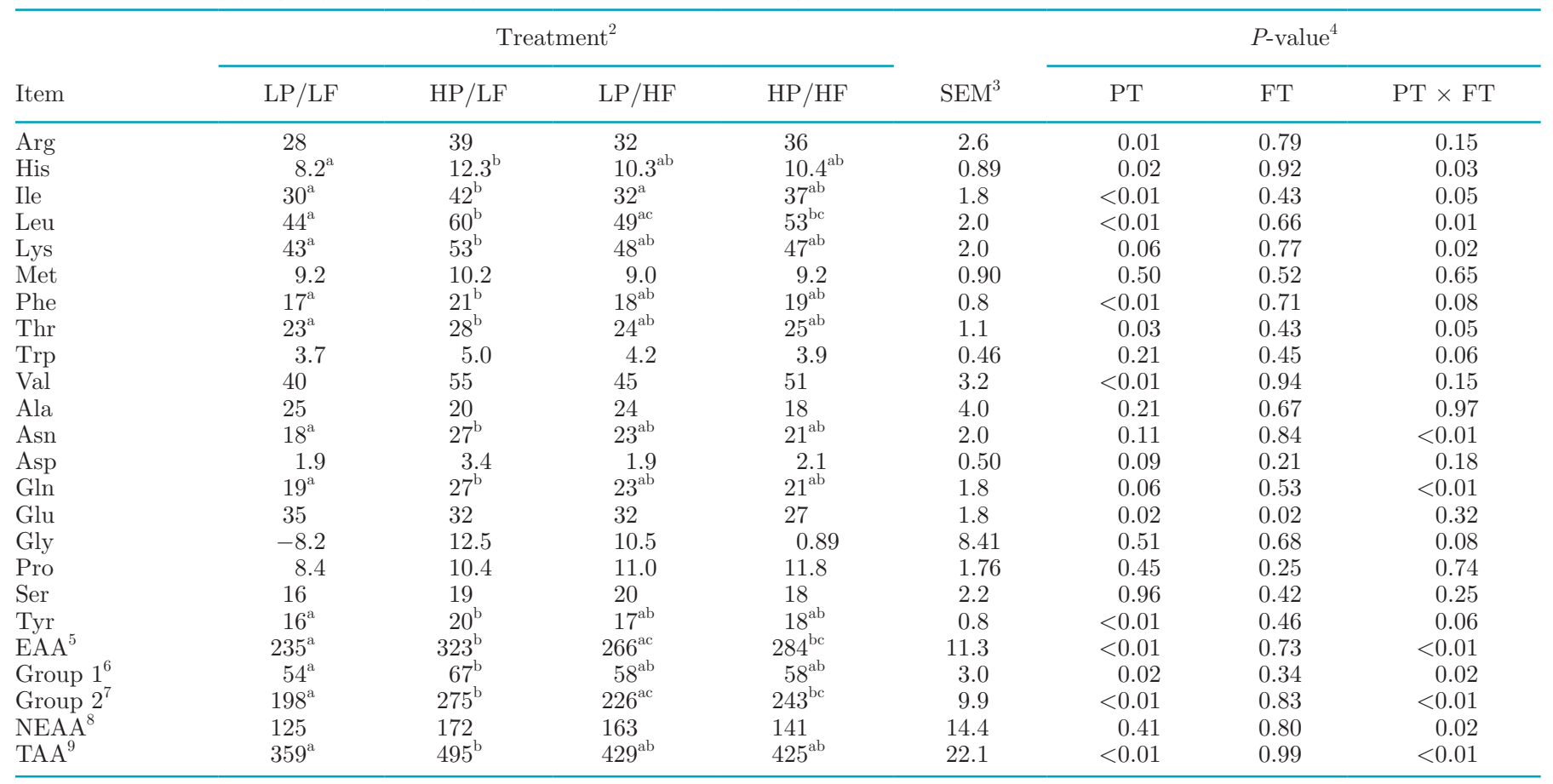

${ }^{\mathrm{a}-\mathrm{c}}$ Means within a row with no common superscripts differ $(P<0.05)$.

${ }^{1}$ Data are LSM from d 28 of the experimental period where measurements on d 28 of the control period are used as covariates.

${ }^{2} \mathrm{LP} / \mathrm{LF}=$ basal TMR fed at $95 \%$ of control ad libitum intake with no protein or fat supplement; HP/LF = TMR fed at $95 \%$ of control ad libitum intake supplemented daily with $2.0 \mathrm{~kg}$ of SoyPass + RaPass (Borregaard LignoTech, Sarpsborg, Norway) on a DM basis; LP/HF $=$ TMR fed at $95 \%$ of control ad libitum intake supplemented daily with $0.68 \mathrm{~kg}$ of Hidropalm (Norel Animal Nutrition, Madrid, Spain) on a DM basis; HP/HF $=$ TMR fed at $95 \%$ of control ad libitum intake supplemented daily with $2.0 \mathrm{~kg}$ of SoyPass + RaPass and $0.68 \mathrm{~kg}$ of Hidropalm on a DM basis. ${ }^{3} \mathrm{n}=14$.

${ }^{4} \mathrm{PT}=$ effect of energy from protein; FT $=$ effect of energy from fat.

${ }^{5} \mathrm{EAA}=$ Arg, His, Ile, Leu, Lys, Met, Phe, Thr, Trp, Val.

${ }^{6}$ Group $1=$ His, Met, Phe + Tyr, Trp.

${ }^{7}$ Group $2=$ Arg, Ile, Leu, Lys, Thr, Val.

${ }^{8} \mathrm{NEAA}=$ Ala, Asn, Asp, Gln, Glu, Gly, Pro, Ser, Tyr.

${ }^{9}$ Total $\mathrm{AA}=\mathrm{EAA}+\mathrm{NEAA}$. 


\section{DISCUSSION}

Results presented here complement previously reported daily lactation performance, digestibility, and milk FA composition (Nichols et al., 2018). In the present paper, we report milk yield and composition on an hourly basis where PT and FT independently and additively stimulated total milk and lactose yield, PT increased protein yield and tended to increase fat yield, and FT increased fat yield and tended to increase protein yield. Dry matter intake did not differ from the designed differences, as described by Nichols et al. (2018). Therefore, delivery of aminogenic and lipogenic nutrients as precursor substrates in circulation for mammary gland use arose from dietary supplementation of RP protein or rumen-inert hydrogenated palm FA. Here we investigated how local mammary mechanisms were affected to produce similar levels of milk lactose, protein, and fat when aminogenic versus lipogenic diets were fed.

\section{Mammary Glucose Balance}

Lactose yield increased independently and additively in response to PT and FT. A relationship exists between protein supplementation and lactose yield where AA increase whole-body appearance of glucose through increased true appearance across the splanchnic tissues, mainly through hepatic gluconeogenesis (Galindo et al., 2011). Many research groups have reported increases in

Table 5. Whole-mammary gland plasma flow and clearances of AA in lactating dairy cows fed the basal diet (LP/LF) or diets supplemented with energy from protein $(\mathrm{HP} / \mathrm{LF})$, fat $(\mathrm{LP} / \mathrm{HF})$, or protein and fat $(\mathrm{HP} / \mathrm{HF})^{1}$

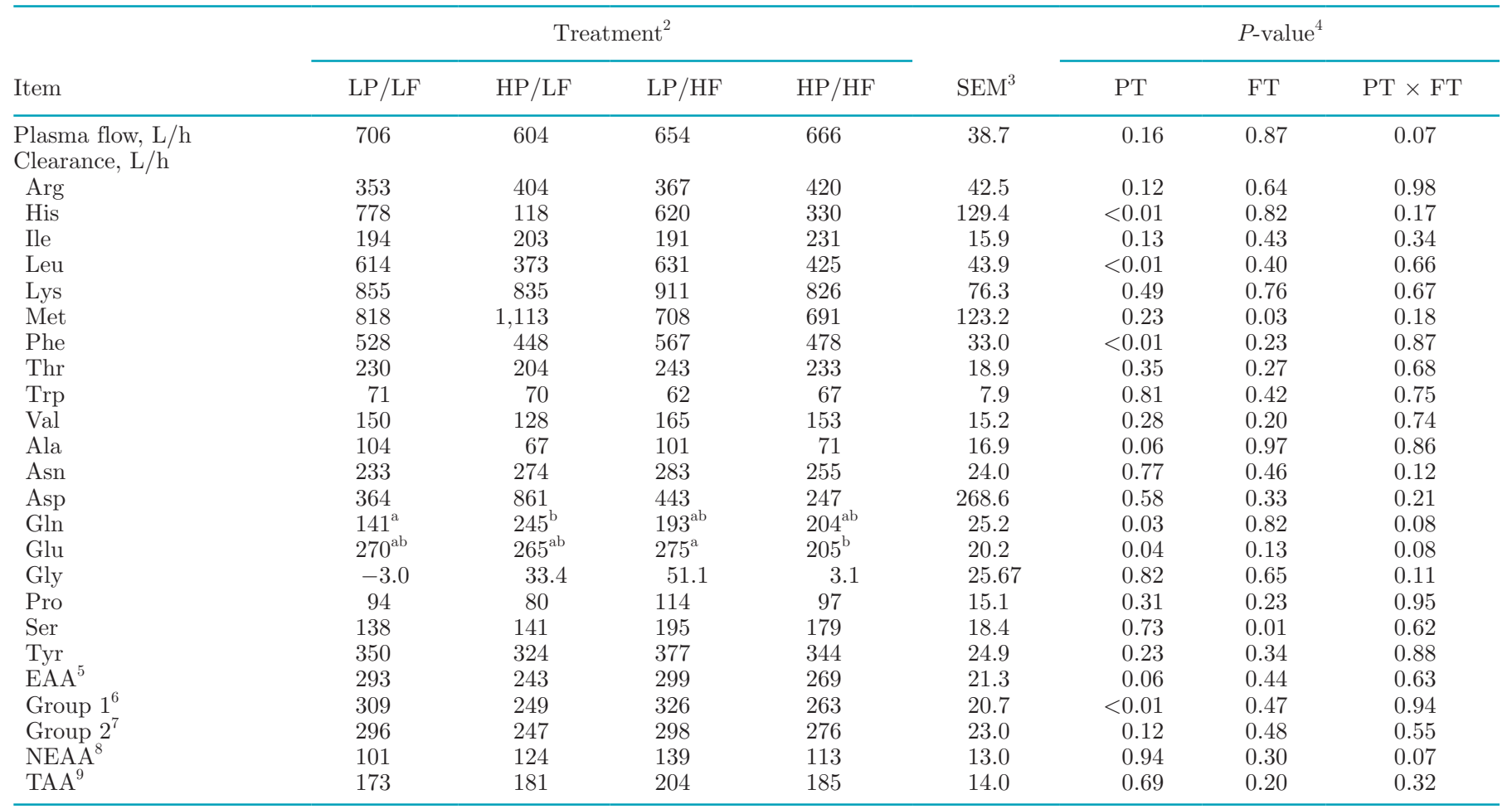

a,b Means within a row with no common superscripts differ $(P<0.05)$.

${ }^{1}$ Data are LSM calculated from measurements on d 28 of the experimental period where calculations from d 28 of the control period are used as covariates.

${ }^{2} \mathrm{LP} / \mathrm{LF}=$ basal TMR fed at $95 \%$ of control ad libitum intake with no protein or fat supplement; HP/LF = TMR fed at $95 \%$ of control ad libitum intake supplemented daily with $2.0 \mathrm{~kg}$ of SoyPass + RaPass (Borregaard LignoTech, Sarpsborg, Norway) on a DM basis; LP/HF $=$ TMR fed at $95 \%$ of control ad libitum intake supplemented daily with $0.68 \mathrm{~kg}$ of Hidropalm (Norel Animal Nutrition, Madrid, Spain) on a DM basis; HP/HF $=$ TMR fed at $95 \%$ of control ad libitum intake supplemented daily with $2.0 \mathrm{~kg}$ of SoyPass + RaPass and $0.68 \mathrm{~kg}$ of Hidropalm on a DM basis.

${ }^{3} \mathrm{n}=14$

${ }^{4} \mathrm{PT}=$ effect of energy from protein; FT $=$ effect of energy from fat.

${ }^{5} \mathrm{EAA}=$ Arg, His, Ile, Leu, Lys, Met, Phe, Thr, Trp, Val.

${ }^{6}$ Group 1 = His, Met, Phe + Tyr, Trp.

${ }^{7}$ Group 2 = Arg, Ile, Leu, Lys, Thr, Val.

${ }^{8} \mathrm{NEAA}=$ Ala, Asn, Asp, Gln, Glu, Gly, Pro, Ser, Tyr.

${ }^{9}$ Total $\mathrm{AA}=\mathrm{EAA}+\mathrm{NEAA}$. 
Table 6. Mammary gland uptakes $(\mathrm{mmol} / \mathrm{h})$ of AA in lactating dairy cows fed the basal diet (LP/LF) or diets supplemented with energy from protein $(\mathrm{HP} / \mathrm{LF})$, fat $(\mathrm{LP} / \mathrm{HF})$, or protein and fat $(\mathrm{HP} / \mathrm{HF})^{1}$

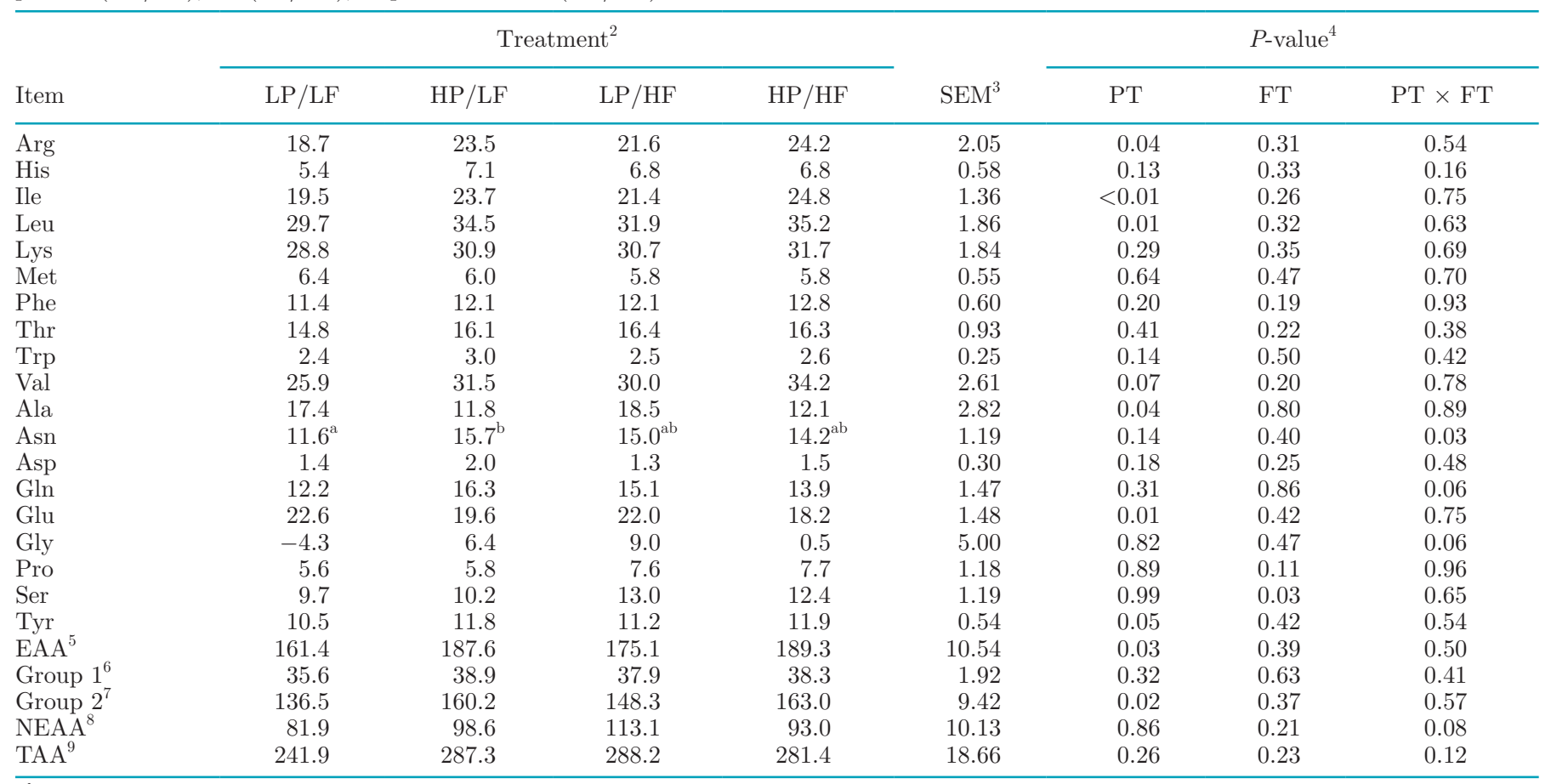

$\overline{\mathrm{a}, \mathrm{b}}$ Means within a row with no common superscripts differ $(P<0.05)$.

${ }^{1}$ Data are LSM calculated from measurements on d 28 of the experimental period where calculations from d 28 of the control period are used as covariates.

${ }^{2} \mathrm{LP} / \mathrm{LF}=$ basal TMR fed at $95 \%$ of control ad libitum intake with no protein or fat supplement; HP/LF = TMR fed at $95 \%$ of control ad libitum intake supplemented daily with $2.0 \mathrm{~kg}$ of SoyPass + RaPass (Borregaard LignoTech, Sarpsborg, Norway) on a DM basis; LP/HF = TMR fed at $95 \%$ of control ad libitum intake supplemented daily with $0.68 \mathrm{~kg}$ of Hidropalm (Norel Animal Nutrition, Madrid, Spain) on a DM basis; HP/HF $=\mathrm{TMR}$ fed at $95 \%$ of control ad libitum intake supplemented daily with $2.0 \mathrm{~kg}$ of SoyPass + RaPass and $0.68 \mathrm{~kg}$ of Hidropalm on a DM basis. ${ }^{3} \mathrm{n}=14$.

${ }^{4} \mathrm{PT}=$ effect of energy from protein; FT $=$ effect of energy from fat.

${ }^{5} \mathrm{EAA}=$ Arg, His, Ile, Leu, Lys, Met, Phe, Thr, Trp, Val.

${ }^{6}$ Group $1=$ His, Met, Phe + Tyr, Trp.

${ }^{7}$ Group 2 = Arg, Ile, Leu, Lys, Thr, Val.

${ }^{8} \mathrm{NEAA}=$ Ala, Asn, Asp, Gln, Glu, Gly, Pro, Ser, Tyr.

${ }^{9}$ Total $\mathrm{AA}=\mathrm{EAA}+\mathrm{NEAA}$.

whole-body glucose appearance, total milk yield, and lactose yield in response to increased postruminal AA supply (Clark et al., 1977; Lemosquet et al., 2009a; Galindo et al., 2011). Thus, we hypothesized that AA from PT would increase hepatic glucose production to support milk lactose yield, which would be reflected in higher arterial glucose and mammary glucose uptake. However, the approximately $90 \mathrm{~g} / \mathrm{d}$ increase in lactose yield observed on HP compared with LP diets did not coincide with an increase in mammary glucose uptake. Given that fat yield, and therefore presumably glucose requirements for glycerol and NADPH related to de novo FA synthesis, did not decrease, glucose use for other purposes must have decreased. The calculated excess glucose uptake relative to that required for lactose and fat synthesis decreased numerically $(\sim 70 \mathrm{~g} / \mathrm{d})$ on HP compared with LP diets, which may indicate reduced contribution of glucose to glycolysis and the tricarboxylic acid cycle. In contrast to AA, LCFA do not yield direct glucose precursors. With regards to the effect of FT on lactose yield, we hypothesized, in line with others (Grummer and Carroll, 1991; Chilliard, 1993; Hammon et al., 2008), that reduction in mammary de novo FA synthesis and the associated glucose utilization to provide NADPH for this synthesis could have contributed glucose for lactose production on $\mathrm{HF}$ diets. However, even with the assumptions that $100 \%$ NADPH required for de novo FA synthesis comes from glucose and that some mixed-source C16 FA shifted from de novo to preformed FA, this contribution remains small ( $\sim 12 \mathrm{~g} / \mathrm{d}$; Nichols et al., 2018) and cannot have covered the approximately $80 \mathrm{~g} / \mathrm{d}$ increase in 
lactose yield observed on HF compared with LF diets. Therefore, it could again be suspected that glucose was made available for lactose synthesis through increased arterial concentration or mammary glucose uptake in response to FT. However, in contrast to these hypotheses, we found no effect of FT on plasma glucose concentration or mammary glucose uptake.

Overall, the mammary gland sequestered glucose in excess of estimated requirements for lactose and fat synthesis, assuming that 1.05 and $0.31 \mathrm{~g}$ of glucose is required to synthesize $1 \mathrm{~g}$ of lactose and fat, respectively (Dijkstra et al., 1996). On average across all diets, $61 \%$ of glucose uptake contributed to lactose synthesis. This level of transfer efficiency is similar to that of Cant et al. (1993a), who observed 57 and $77 \%$ transfer of mammary extracted glucose into lactose when casein was infused abomasally with and without dietary fat supplementation, respectively. However, it appears that when mammary glucose balance is positive, priority for glucose use is not directed infinitely toward further stimulation of lactose synthesis. Indeed, when Cant et al. (2002) infused glucose into the external iliac artery, lactose yield increased 18\%, whereas glucose uptake increased 39\%. Similarly, Rigout et al. (2002) duodenally infused glucose in graded amounts and observed excess mammary glucose uptake relative to lactose output at all doses. Of measured glucose uptake in this study, FT increased glucose required for fat synthesis, but this is likely an overestimation reflected in the calculation because FT also decreased de novo FA synthesis in the present experiment (Nichols et al., 2018). However, although mammary net LCFA uptake

Table 7. Mammary gland AA uptake:milk protein output ratios in lactating dairy cows fed the basal diet (LP/LF) or diets supplemented with energy from protein $(\mathrm{HP} / \mathrm{LF})$, fat $(\mathrm{LP} / \mathrm{HF})$, or protein and fat $(\mathrm{HP} / \mathrm{HF})^{1}$

\begin{tabular}{|c|c|c|c|c|c|c|c|c|}
\hline Item & \multicolumn{4}{|c|}{ Treatment $^{2}$} & $\mathrm{SEM}^{3}$ & \multicolumn{3}{|c|}{$P$-value ${ }^{4}$} \\
\hline $\operatorname{Arg}$ & 2.96 & 3.06 & 2.70 & 2.86 & 0.159 & 0.42 & 0.18 & 0.85 \\
\hline Ile & 1.20 & 1.36 & 1.20 & 1.36 & 0.045 & $<0.01$ & 0.95 & 0.99 \\
\hline Leu & $1.05^{\mathrm{a}}$ & $1.18^{\mathrm{b}}$ & $1.09^{\mathrm{ac}}$ & $1.15^{\mathrm{bc}}$ & 0.022 & $<0.01$ & 0.66 & 0.06 \\
\hline Lys & 1.36 & 1.34 & 1.38 & 1.31 & 0.036 & 0.20 & 0.97 & 0.42 \\
\hline Thr & 0.99 & 1.01 & 1.02 & 0.99 & 0.030 & 0.81 & 0.96 & 0.36 \\
\hline Trp & 1.09 & 0.92 & 0.96 & 0.85 & 0.095 & 0.10 & 0.25 & 0.74 \\
\hline Val & 1.24 & 1.42 & 1.31 & 1.44 & 0.077 & 0.05 & 0.56 & 0.78 \\
\hline Ala & 1.23 & 0.78 & 1.18 & 0.78 & 0.163 & 0.01 & 0.87 & 0.90 \\
\hline Asn & 1.01 & 1.25 & 1.24 & 1.07 & 0.079 & 0.58 & 0.70 & $<0.01$ \\
\hline Asp & 0.09 & 0.12 & 0.08 & 0.08 & 0.020 & 0.50 & 0.21 & 0.54 \\
\hline Gln & 0.52 & 0.63 & 0.60 & 0.53 & 0.052 & 0.69 & 0.85 & 0.08 \\
\hline $\mathrm{EAA}^{5}$ & 1.17 & 1.29 & 1.22 & 1.25 & 0.034 & 0.04 & 0.91 & 0.20 \\
\hline Group $1^{6}$ & 0.92 & 0.94 & 0.93 & 0.90 & 0.022 & 0.73 & 0.38 & 0.19 \\
\hline Group $2^{7}$ & 1.24 & 1.38 & 1.29 & 1.34 & 0.042 & 0.04 & 0.82 & 0.27 \\
\hline NEAA $^{8}$ & 0.45 & 0.50 & 0.59 & 0.46 & 0.049 & 0.44 & 0.38 & 0.06 \\
\hline TAA $^{9}$ & 0.76 & 0.84 & 0.86 & $\begin{array}{l}.40 \\
0.79\end{array}$ & 0.035 & $\begin{array}{l}0.44 \\
0.77\end{array}$ & $\begin{array}{l}0.08 \\
0.45\end{array}$ & 0.05 \\
\hline
\end{tabular}

${ }^{\mathrm{a}-\mathrm{c}}$ Means within a row with no common superscripts differ $(P<0.05)$.

${ }^{1}$ Data are LSM calculated from measurements on d 28 of the experimental period where calculations from d 28 of the control period are used as covariates. The AA composition in milk protein was estimated using Mepham (1987) and Lapierre et al. (2012).

${ }^{2} \mathrm{LP} / \mathrm{LF}=$ basal TMR fed at $95 \%$ of control ad libitum intake with no protein or fat supplement; HP/LF = TMR fed at $95 \%$ of control ad libitum intake supplemented daily with $2.0 \mathrm{~kg}$ of SoyPass + RaPass (Borregaard LignoTech, Sarpsborg, Norway) on a DM basis; LP/HF = TMR fed at $95 \%$ of control ad libitum intake supplemented daily with $0.68 \mathrm{~kg}$ of Hidropalm (Norel Animal Nutrition, Madrid, Spain) on a DM basis; HP/HF $=$ TMR fed at $95 \%$ of control ad libitum intake supplemented daily with $2.0 \mathrm{~kg}$ of SoyPass + RaPass and $0.68 \mathrm{~kg}$ of Hidropalm on a DM basis. ${ }^{3} \mathrm{n}=14$

${ }^{4} \mathrm{PT}=$ effect of energy from protein; FT $=$ effect of energy from fat.

${ }^{5} \mathrm{EAA}=$ Arg, His, Ile, Leu, Lys, Met, Phe, Thr, Trp, Val.

${ }^{6}$ Group 1 = His, Met, Phe + Tyr, Trp.

${ }^{7}$ Group $2=$ Arg, Ile, Leu, Lys, Thr, Val.

${ }^{8}$ NEAA = Ala, Asn, Asp, Gln, Glu, Gly, Pro, Ser, Tyr.

${ }^{9}$ Total $\mathrm{AA}=\mathrm{EAA}+\mathrm{NEAA}$. 
increased in response to FT, it did not meet the requirements for LCFA $(\geq 16 \mathrm{C})$ production. Net LCFA uptake did not equilibrate with LCFA output in milk on any treatment in this experiment, but $2 \mathrm{C}$ balance was positive. The positive $2 \mathrm{C}$ balance may indicate synthesis of $\mathrm{C} 16$ from acetate and $\mathrm{BHB}$, which may have been released from the gland in venous drainage, giving rise to the observed net release of NEFA. This synthesis and release would contribute to the observed shortfall in net mammary supply of LCFA from blood relative to milk LCFA. A possible use for excess glucose uptake not sequestered in lactose may have been oxidation to support glycerol synthesis and to yield NADPH for C16 synthesis from excess acetate to compensate for the apparently deficient preformed LCFA uptake (Dils, 1983). Excess mammary glucose also is oxidized to provide carbon for NEAA synthesis and to yield ATP for fat, protein, and lactose synthesis (Smith et al., 1983; Qiao et al., 2005). In fed goats and cows, respectively, 25 and $11 \%$ of intramammary glucose was oxidized, which contributed 39 and $24 \%$ of $\mathrm{CO}_{2}$ produced by the gland (Bickerstaffe et al., 1974; Linzell, 1974).

Although mammary priority for glucose is high relative to other body tissues, rates of glucose sequestration and secretion of lactose in milk appear not to be correlated with circulating glucose concentrations in lactating dairy cows (Cant et al., 1993a; Nielsen et al., 2001; Qiao et al., 2005). In agreement, glucose clearance in this study was not affected by PT or FT, suggesting that capacity of glucose transport did not limit glucose uptake. Translocation of glucose into mammary cells is faster than its rate of metabolism (Xiao and Cant, 2005), and extraction can be influenced by factors such as mammary biosynthetic capacity rather than physiological substrate supply (Miller et al., 1991; Cant et al., 1993a). Glucose uptake covered requirements for lactose yield without supplementation of PT or FT, as evidenced by the excess glucose uptake on LP/LF. As such, stimulation of lactose yield with PT and FT must have been driven by factors other than mammary glucose supply. In line with this observation, Lemosquet et al. (2009a) infused propionate and casein and observed no increase in glucose uptake, but lactose yield increased in response to casein. Lemosquet et al. (2009b) and Lapierre et al. (2010) suggested that glucose availability is not always the driving mechanism to increase lactose synthesis, as evidenced when whole-body glucose appearance increases with no appreciable change in lactose yield. Lactose synthesis may be largely regulated by mammary mechanisms independent of glucose supply, such as glucose phosphorylation and transport capacity, and concentrations of metabolites glucose-6-P and glucose-1-P (Xiao and Cant, 2005). The synthetic processes for milk protein and fat may also play a role in determining total milk yield through stimulatory effects on cell signaling pathways dictating overall mammary synthetic capacity (Nichols et al., 2017) or through effects on hormones and enzymes controlling flux through the lactose synthesis pathway (Anderson et al., 2007). Taken together, results of previous studies

Table 8. Arterial plasma concentrations of metabolites and hormones in lactating dairy cows fed the basal diet (LP/LF) or diets supplemented with energy from protein $(\mathrm{HP} / \mathrm{LF})$, fat $(\mathrm{LP} / \mathrm{HF})$, or protein and fat $(\mathrm{HP} / \mathrm{HF})^{1}$

\begin{tabular}{|c|c|c|c|c|c|c|c|c|}
\hline Item $^{2}$ & \multicolumn{4}{|c|}{ Treatment $^{3}$} & $\mathrm{SEM}^{4}$ & \multicolumn{3}{|c|}{$P$-value ${ }^{5}$} \\
\hline Glucose, $\mathrm{m} M$ & 2.62 & 2.66 & 2.61 & 2.68 & 0.060 & 0.39 & 0.96 & 0.76 \\
\hline Acetate, $\mathrm{m} M$ & $1.63^{\mathrm{ab}}$ & $1.85^{\mathrm{a}}$ & $1.65^{\mathrm{ab}}$ & $1.47^{\mathrm{b}}$ & 0.094 & 0.84 & 0.06 & 0.04 \\
\hline NEFA, $\mu M$ & 96 & 90 & 117 & 115 & 5.0 & 0.36 & $<0.01$ & 0.61 \\
\hline TAG, $\mu M$ & 52 & 52 & 64 & 60 & 2.5 & 0.30 & $<0.01$ & 0.37 \\
\hline $\mathrm{GH}, \mu \mathrm{g} / \mathrm{L}$ & 3.37 & 3.48 & 3.47 & 3.71 & 0.302 & 0.56 & 0.60 & 0.83 \\
\hline $\mathrm{IGF}-1, \mu \mathrm{g} / \mathrm{L}$ & 3.15 & 3.20 & 3.21 & 3.66 & 0.277 & 0.38 & 0.35 & 0.47 \\
\hline Leptin, $\mu \mathrm{g} / \mathrm{L}$ & 6.51 & 6.47 & 6.57 & 6.48 & 0.071 & 0.37 & 0.59 & 0.74 \\
\hline Insulin, $\mu \mathrm{g} / \mathrm{L}$ & $1.31^{\mathrm{ab}}$ & $1.49^{\mathrm{a}}$ & $1.22^{\mathrm{bc}}$ & $1.11^{\mathrm{c}}$ & 0.052 & 0.53 & $<0.01$ & $<0.01$ \\
\hline
\end{tabular}

\footnotetext{
${ }^{\mathrm{a}-\mathrm{c}}$ Means within a row with no common superscripts differ $(P<0.05)$.

${ }^{1}$ Data are LSM from d 28 of the experimental period where measurements on d 28 of the control period are used as covariates.

${ }^{2} \mathrm{NEFA}=$ nonesterified fatty acids; TAG $=$ triacylglycerides; LCFA $=$ long-chain fatty acids; $\mathrm{GH}=$ growth hormone.

${ }^{3} \mathrm{LP} / \mathrm{LF}=$ basal TMR fed at $95 \%$ of control ad libitum intake with no protein or fat supplement; HP $/ \mathrm{LF}=\mathrm{TMR}$ fed at $95 \%$ of control ad libitum intake supplemented daily with $2.0 \mathrm{~kg}$ of SoyPass + RaPass (Borregaard LignoTech, Sarpsborg, Norway) on a DM basis; LP/HF = TMR fed at $95 \%$ of control ad libitum intake supplemented daily with $0.68 \mathrm{~kg}$ of Hidropalm (Norel Animal Nutrition, Madrid, Spain) on a DM basis; HP/HF $=$ TMR fed at $95 \%$ of control ad libitum intake supplemented daily with $2.0 \mathrm{~kg}$ of SoyPass + RaPass and $0.68 \mathrm{~kg}$ of Hidropalm on a DM basis. ${ }^{4} \mathrm{n}=14$.

${ }^{5} \mathrm{PT}=$ effect of energy from protein; $\mathrm{FT}=$ effect of energy from fat.
} 
Table 9. Mammary gland arteriovenous (AV) differences, clearances, and uptakes of metabolites in lactating dairy cows fed the basal diet (LP/ $\mathrm{LF})$ or diets supplemented with energy from protein $(\mathrm{HP} / \mathrm{LF})$, fat $(\mathrm{LP} / \mathrm{HF})$, or protein and fat $(\mathrm{HP} / \mathrm{HF})^{1}$

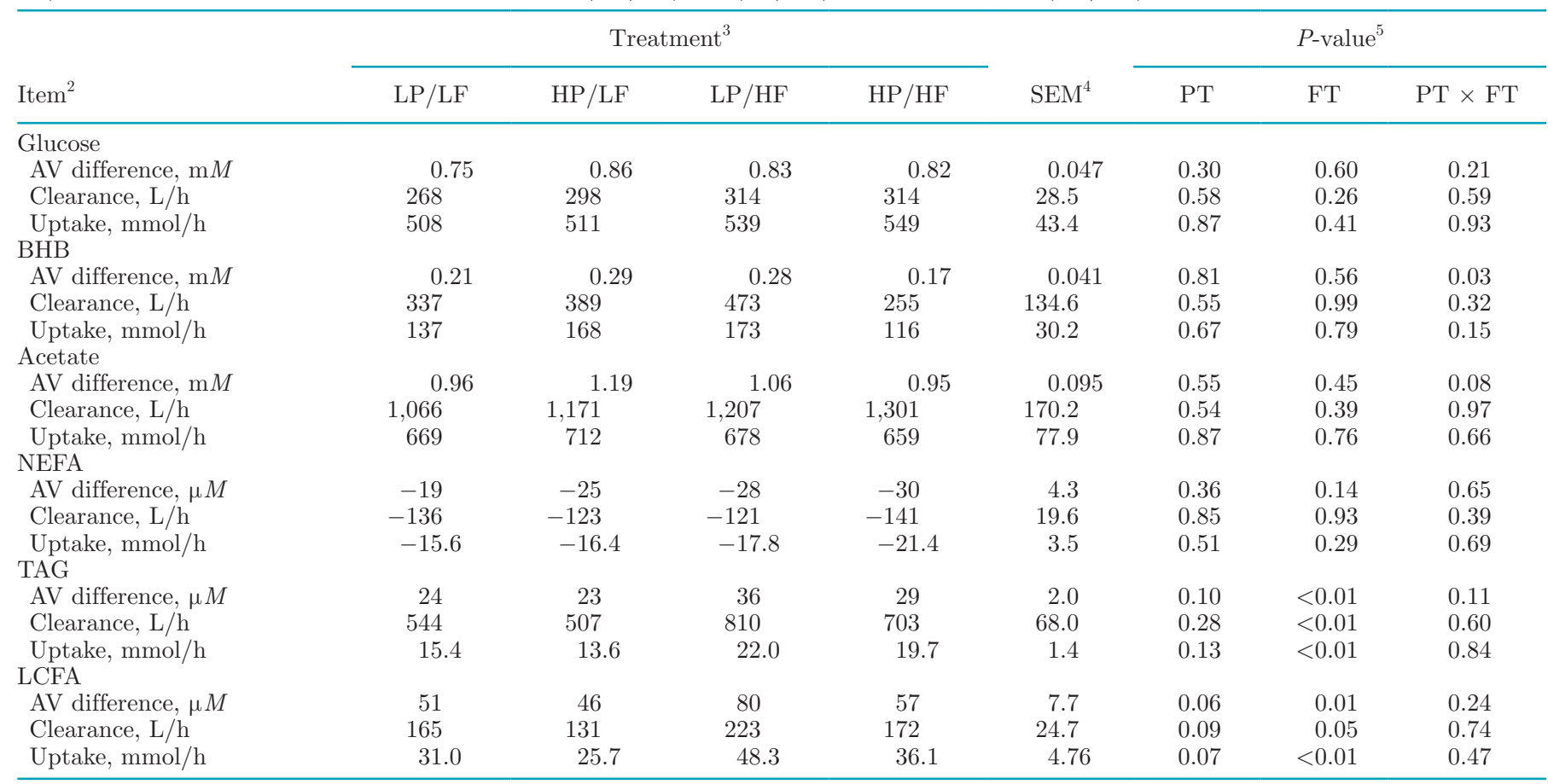

${ }^{1}$ Data are LSM calculated from measurements on d 28 of the experimental period where calculations from d 28 of the control period are used as covariates.

${ }^{2} \mathrm{NEFA}=$ nonesterified fatty acids; TAG $=$ triacylglycerides; $\mathrm{LCFA}=$ long-chain fatty acids.

${ }^{3} \mathrm{LP} / \mathrm{LF}=$ basal TMR fed at $95 \%$ of control ad libitum intake with no protein or fat supplement; HP/LF $=$ TMR fed at $95 \%$ of control ad libitum intake supplemented daily with $2.0 \mathrm{~kg}$ of SoyPass + RaPass (Borregaard LignoTech, Sarpsborg, Norway) on a DM basis; LP/HF = TMR fed at $95 \%$ of control ad libitum intake supplemented daily with $0.68 \mathrm{~kg}$ of Hidropalm (Norel Animal Nutrition, Madrid, Spain) on a DM basis; HP/HF $=$ TMR fed at $95 \%$ of control ad libitum intake supplemented daily with $2.0 \mathrm{~kg}$ of SoyPass + RaPass and $0.68 \mathrm{~kg}$ of Hidropalm on a DM basis. ${ }^{4} \mathrm{n}=14$.

${ }^{5} \mathrm{PT}=$ effect of energy from protein; $\mathrm{FT}=$ effect of energy from fat.

along with data presented here suggest that although glucose is necessary to support lactose yield, glucose availability per se is not the driving force stimulating lactose synthesis in mid-lactation cows, and that mammary regulation of milk production is dependent on factors other than mammary glucose supply.

\section{AA Utilization with Energy from Protein}

Total plasma EAA concentration increased in response to PT, in particular at the LF level. Arterial concentrations of all individual EAA increased in response to PT, with the exception of Met. This indicates intestinal absorption of the RP protein supplement in response to PT, agrees with our hypothesis that AA from PT stimulated the increase in milk protein yield, and agrees with previously reported positive effects of postruminal protein supply on plasma AA concentrations (Doepel and Lapierre, 2010; Rius et al., 2010b; Nichols et al., 2016). Considering the classification of AA as group 1 (His, Met, Phe + Tyr, Trp) or group 2
(Arg, Ile, Leu, Lys, Thr, Val) based on their respective $\mathrm{U}: \mathrm{O}$ ratios close to or greater than unity (Mepham, 1987), nuances in mammary AA metabolism can be examined. In the present study, U:O of total group 1 AA was less than unity. Previous studies have shown variability in this canonical 1:1 relationship during abomasal infusions of casein or of EAA mixtures in the profile of casein (Raggio et al., 2006; Doepel and Lapierre, 2010, 2011). A novel element of the current study is that it used a relatively large number of cows managed under a more practical setting relative to several mammary net balance studies that have been conducted previously. As such, we expected a certain level of variation in this pattern. Factors such as lack of steady-state feeding, fewer blood samples taken over the milking interval, and larger cow variation are limitations of the current study and place a limit of accuracy on the U:O measurements that should be accepted. Although the absolute values for $\mathrm{U}: \mathrm{O}$ for the group $1 \mathrm{AA}$ and for total AA indicate some discrepancy on the whole, the relative differences in response to PT 
(no effect on the total group $1 \mathrm{AA}$, increased group 2 AA) align with other studies performing mammary AA net balance under conditions of supplemental MP (Raggio et al., 2006; Haque et al., 2015). Previous mammary balance studies have produced total AA balances greater than or equal to unity (Raggio et al., 2006; Doepel and Lapierre, 2010), but some studies present values near 0.90 (Larsen et al., 2014, 2015), with values ranging from 0.83 to 0.96 within a study (Larsen et al., 2014). Furthermore, in the current study, when U:O for total AA was calculated on an $\mathrm{N}$ basis, the ratio increased to $0.85,0.91,0.93$, and 0.88 for $\mathrm{LP} / \mathrm{LF}, \mathrm{HP} /$ $\mathrm{LF}, \mathrm{LP} / \mathrm{HF}$, and $\mathrm{HP} / \mathrm{HF}$, respectively. On average, $11 \%$ of milk AA-N was not accounted for, which either was derived from unquantified $\mathrm{N}$ sources in the mammary gland such as NPN or AA peptides, or represents a discrepancy in our practical mammary net balance (Bequette et al., 1998).

Increased MP supply yields increased blood AA concentrations and transfer of AA into milk but also increased AA catabolism (Lapierre et al., 2005). In response to PT, arterial concentration of group $1 \mathrm{AA}$ increased, but mammary uptake was not affected and clearance tended to decrease. Decreased mammary affinity for group $1 \mathrm{AA}$ suggests that their potential for transport into mammary cells was maximized below the HP level. Although PT did contribute to absorbed group 1 AA, a lack of concomitant mammary uptake might allow hepatic catabolism of these AA at the HP level. Group 1 AA are subject to hepatic removal, which is also linked with mammary requirements (Lapierre et al., 2005), and hepatic flux of His, Met, and Phe in particular responds to MP supply by increasing linearly with increased MP level (Raggio et al., 2004). This agrees with our observation of decreased mammary affinity for total group $1 \mathrm{AA}$ and increased plasma urea concentration in response to PT, and may suggest that in this case hepatic catabolism is responding to mammary gland utilization (Lobley and Lapierre, 2003). The increase in arterial concentration of group 2 AA in response to $\mathrm{PT}$ was accompanied by increased mammary uptake. Increased milk protein yield stimulated by $\mathrm{PT}$ was likely supported by mammary extraction of group $2 \mathrm{AA}$, of which the $\mathrm{U}: \mathrm{O}$ ratio increased in response to PT. Excess uptake of group $2 \mathrm{AA}$ is used for intramammary NEAA synthesis (Mepham, 1987; Lapierre et al., 2012) in support of milk protein. Our observations agree with those of others when EAA supply is abundant and group 2 AA uptake contributes to NEAA synthesis (Raggio et al., 2006; Doepel and Lapierre, 2010, 2011) and are supported here by no appreciable change in NEAA uptake on HP diets and increased milk protein yield in response to PT.

\section{AA Utilization with Energy from Fat}

A second novel element of this study is the investigation of mammary gland metabolite utilization during fat supplementation at 2 levels of MP supply. In response to FT, milk protein yield tended to increase, but

Table 10. Calculated mammary gland nutrient balance in lactating dairy cows fed the basal diet (LP/LF) or diets supplemented with energy from protein $(\mathrm{HP} / \mathrm{LF})$, fat $(\mathrm{LP} / \mathrm{HF})$, or protein and fat $(\mathrm{HP} / \mathrm{HF})^{1}$



${ }^{1}$ Estimated based on calculations of Dijkstra et al. (1996).

${ }^{2} \mathrm{LP} / \mathrm{LF}=$ basal TMR fed at $95 \%$ of control ad libitum intake with no protein or fat supplement; HP $/ \mathrm{LF}=\mathrm{TMR}$ fed at $95 \%$ of control ad libitum intake supplemented daily with $2.0 \mathrm{~kg}$ of SoyPass + RaPass (Borregaard LignoTech, Sarpsborg, Norway) on a DM basis; LP/HF = TMR fed at $95 \%$ of control ad libitum intake supplemented daily with $0.68 \mathrm{~kg}$ of Hidropalm (Norel Animal Nutrition, Madrid, Spain) on a DM basis; HP/HF $=$ TMR fed at $95 \%$ of control ad libitum intake supplemented daily with $2.0 \mathrm{~kg}$ of SoyPass + RaPass and $0.68 \mathrm{~kg}$ of Hidropalm on a DM basis. ${ }^{3} \mathrm{n}=14$.

${ }^{4} \mathrm{PT}=$ effect of energy from protein; FT $=$ effect of energy from fat.

${ }^{5}$ Uptake - required for lactose - required for fat.

${ }^{6} 2 \mathrm{C}=$ acetate + BHB.

${ }^{7}$ Long-chain fatty acid. 
no significant differences in AA uptake, with the exception of Ser, or U:O of any AA group, were found. At the LP level, the addition of HF numerically increased milk protein yield and uptake of all AA groups compared with LP/LF. Although statistical differences were not detected, this magnitude of extra uptake would support the tendency for milk protein yield to increase by 1.8 $\mathrm{g} / \mathrm{h}$ in response to FT. When HP and HF were supplied together, the dynamics of mammary AA uptake and capacity for milk protein synthesis achieved by PT was not affected by FT. A PT $\times$ FT interaction affected arterial concentrations of all EAA groups where the increase in response to $\mathrm{PT}$ was greater at the $\mathrm{LF}$ level compared with the HF level, but the same level of EAA uptake was achieved by HP regardless of dietary fat level. For arterial concentrations to be lower on $\mathrm{HP} / \mathrm{HF}$ with the same level of protein intake as $\mathrm{HP} / \mathrm{LF}$ with no detectable increase in mammary gland uptake, the addition of HF to HP must have affected intestinal EAA absorption, metabolism at the level of the portal-drained viscera or liver, or their partitioning toward extramammary peripheral tissues. Plasma insulin concentration was decreased by FT and lowest with HF at the HP level, which suggests that AA partitioning toward extramammary peripheral tissues was not stimulated. Hammon et al. (2008) did not report significant changes in flux of any AA through the portal-drained viscera when a fat-supplemented diet was compared with a starch-based diet. Taken together, these findings suggest that changes at the level of intestinal EAA absorption may be the mechanism resulting in lower plasma EAA concentrations when protein is supplemented at the HF level. To our knowledge, no study exists comparing portal-drained viscera or liver flux in mid-lactation cows under conditions of supplementation of extra protein and saturated fat. Regardless of the utilization of EAA when HF is added to HP, the addition of HF to HP did not affect plasma urea concentration, indicating that the same level of AA catabolism occurred at the LF or HF level. Overall, our hypotheses that FT would stimulate mammary AA sequestration or reduce AA catabolism in support of milk protein synthesis were not confirmed, as neither mammary AA sequestration nor milk protein yield were significantly increased and AA catabolism did not decrease in response to FT.

\section{Energetic Substrate Shift with Energy from Protein or Fat}

Arterial glucose concentration was not affected by PT or FT, despite the change in energy supply. If PT stimulated glucose appearance from AA, the higher insulin concentration with HP at the LF level agrees with signaling to extramammary insulin-sensitive tissues such as skeletal muscle and adipose to clear extra glucose from circulation. In contrast, insulin resistance from fat supplementation lessens glucose utilization by peripheral tissues and possibly increases gluconeogenesis from lactate, pyruvate, or AA through glucagon signaling (Benson et al., 2002; Hammon et al., 2008). Availability of LCFA with FT also could stimulate peripheral tissue oxidation of acetate and in turn reduce glucose oxidation. The PT $\times$ FT interaction affecting insulin concentration, resulting in the lowest concentration when HP and HF are supplied together, aligns with the interaction on acetate concentration and suggests reduced glucose storage, a shift in energy precursor for extramammary tissues, and stimulation of lipolysis, which agrees with numerically highest glucose concentration and mammary glucose uptake, lactose yield, and fat yield on $\mathrm{HP} / \mathrm{HF}$.

Arterial concentrations of NEFA and TAG increased in response to $\mathrm{FT}$, in agreement with observations of others (Hammon et al., 2008; Boerman et al., 2015; Nichols et al., 2019), and with the absorption of LCFA from the digestive tract. Plasma NEFA concentrations reflect the increase in endogenous lipid flux on HF diets, possibly caused by enhanced lipolytic activity in the liver and in adipose tissue during fat feeding (Chilliard, 1993), and may have resulted from their incomplete uptake by peripheral tissues after TAG hydrolysis (Grum et al., 1996). Increased mammary AV difference of TAG suggests that mammary TAG hydrolysis increased in response to FT (Cant et al., 1993a). Arterial BHB concentration increased in response to PT, but only at the LF level. Elevated BHB concentrations might be associated with increased arterial concentrations of ketogenic AA Leu and Lys on HP/LF or decreased BHB utilization by nonhepatic tissues (Ørskov et al., 1999), or could be induced by increased butyrate production in the rumen, although the latter is unlikely as DM and NDF digestibility were not affected by PT or FT (Nichols et al., 2018). The interaction on BHB concentration that mirrors that of insulin and acetate suggests that BHB is also responsive to the mechanism of energy precursor repartitioning that seems to occur when energy is supplemented from protein and fat together.

\section{CONCLUSIONS}

Isoenergetic supplementation of aminogenic or lipogenic substrates modified the profile of AA and other metabolites available for mammary metabolism. Energy from protein increased arterial EAA concentration but to a greater extent at the LF level compared with the HF level. This suggests that supplementation with energy from fat alters EAA absorption across the gut or 
utilization of EAA by extramammary tissues, because the same level of mammary EAA uptake was stimulated by HP regardless of dietary fat level. Milk protein yield was supported by increased uptake of group $2 \mathrm{AA}$ in response to energy from protein. Supplementing RP protein and hydrogenated palm FA does not further enhance mammary glucose balance in mid-lactation dairy cows but does increase milk lactose yield. Thus, it appears that factors other than mammary glucose supply stimulate lactose yield when extra energy is supplemented from protein and fat. Further investigation of intramammary synthetic pathways is warranted to obtain a more clear view of how lactose synthesis is affected by AA and other metabolites when mammary glucose supply is not limiting.

\section{ACKNOWLEDGMENTS}

The authors gratefully acknowledge technical assistance from Mieke Langen, Jos Versteegen (Trouw Nutrition Ruminant Research Centre, Boxmeer, the Netherlands), and Jasper te Winkel (student of Wageningen University, Wageningen, the Netherlands). Ultra-performance liquid chromatography was performed in the Lactation Systems Biology Lab at the University of Guelph (Guelph, ON, Canada). This research was conducted by Wageningen University and Research (Wageningen Livestock Research, Wageningen, the Netherlands) and commissioned and funded by the Ministry of Agriculture, Nature and Food Quality (The Hague, the Netherlands) within the framework of Policy Support Research theme "Feed4Foodure" (BO31.03-005-001; TKI-AF12039) and by the Vereniging Diervoederonderzoek Nederland (Rijswijk, the Netherlands).

\section{REFERENCES}

Anderson, S. M., M. C. Rudolph, J. L. McManaman, and M. C. Neville. 2007. Key stages in mammary gland development. Secretory activation in the mammary gland: It's not just about milk protein synthesis! Breast Cancer Res. 9:204.

Benson, J. A., C. K. Reynolds, P. C. Aikman, B. Lupoli, and D. E. Beever. 2002. Effects of abomasal vegetable oil infusion on splanchnic nutrient metabolism in lactating dairy cows. J. Dairy Sci. 85:1804-1814.

Bequette, B. J., F. R. C. Backwell, and L. A. Crompton. 1998. Current concepts of amino acid and protein metabolism in the mammary gland of the lactating ruminant. J. Dairy Sci. 81:2540-2559.

Bickerstaffe, R., E. F. Annison, and J. L. Linzell. 1974. The metabolism of glucose, acetate, lipids and amino acids in lactating dairy cows. J. Agric. Sci. 82:71-85.

Boerman, J. P., S. B. Potts, M. J. VandeHaar, and A. L. Lock. 2015. Effects of partly replacing dietary starch with fiber and fat on milk production and energy partitioning. J. Dairy Sci. 98:7264-7276.

Boogers, I., W. Plugge, Y. Q. Stokkermans, and A. L. L. Duchateau. 2008. Ultra-performance liquid chromatographic analysis of amino acids in protein hydrolysates using an automated pre-column derivatisation method. J. Chromatogr. A 1189:406-409.
Cant, J. P., E. J. DePeters, and R. L. Baldwin. 1993a. Mammary uptake of energy metabolites in dairy cows fed fat and its relationship to milk protein depression. J. Dairy Sci. 76:2254-2265.

Cant, J. P., E. J. DePeters, and R. L. Baldwin. 1993b. Mammary amino acid utilization in dairy cows fed fat and its relationship to milk protein depression. J. Dairy Sci. 76:762-774.

Cant, J. P., D. R. Trout, F. Qiao, and N. G. Purdie. 2002. Milk synthetic response of the bovine mammary gland to an increase in the local concentration of arterial glucose. J. Dairy Sci. 85:494-503.

Casper, D. P., and D. J. Schingoethe. 1989. Model to describe and alleviate milk protein depression in early lactation dairy cows fed a high fat diet. J. Dairy Sci. 72:3327-3335.

Casper, D. P., D. J. Schingoethe, and W. A. Eisenbeisz. 1990. Response of early lactation cows to diets that vary in ruminal degradability of carbohydrates and amount of fat. J. Dairy Sci. 73:425-444.

Chilliard, Y. 1993. Dietary fat and adipose tissue metabolism in ruminants, pigs, and rodents: A review. J. Dairy Sci. 76:3897-3931.

Clark, J. H., H. R. Spires, R. G. Derrig, and M. R. Bennink. 1977. Milk production, nitrogen utilization and glucose synthesis in lactating cows infused postruminally with sodium caseinate and glucose. J. Nutr. 107:631-644.

CVB (Centraal Veevoederbureau). 2008. CVB Table Ruminants 2008, Series No. 43. CVB, The Hague, the Netherlands.

DePeters, E. J., and J. D. Ferguson. 1992. Nonprotein nitrogen distribution in the milk of cows. J. Dairy Sci. 75:3192-3209.

Dijkstra, J., J. France, A. G. Assis, H. D. St. C. Neal, O. F. Campos, and L. M. J. Aroeira. 1996. Simulation of digestion in cattle fed sugarcane: Prediction of nutrient supply for milk production with locally available supplements. J. Agric. Sci. 127:247-260.

Dils, R. R. 1983. Milk fat synthesis. Pages 141-157 in Biochemistry of Lactation. T. B. Mepham, ed. Elsevier, Amsterdam, the Netherlands.

Doepel, L., and H. Lapierre. 2010. Changes in production and mammary metabolism of dairy cows in response to essential and nonessential amino acid infusions. J. Dairy Sci. 93:3264-3274.

Doepel, L., and H. Lapierre. 2011. Deletion of arginine from an abomasal infusion of amino acids does not decrease milk protein yield in Holstein cows. J. Dairy Sci. 94:864-873.

Emery, R. S., L. D. Brown, and J. W. Bell. 1965. Correlation of milk fat with dietary and metabolic factors in cows fed restricted-roughage rations supplemented with magnesium oxide or sodium bicarbonate. J. Dairy Sci. 48:1647-1651.

Galindo, C. E., D. R. Ouellet, D. Pellerin, S. Lemosquet, I. OrtiguesMarty, and H. Lapierre. 2011. Effect of amino acid or casein supply on whole-body, splanchnic, and mammary glucose kinetics in lactating dairy cows. J. Dairy Sci. 94:5558-5568.

Grum, D. E., J. K. Drackley, L. R. Hansen, and J. D. Cremin Jr.. 1996. Production, digestion, and hepatic lipid metabolism of dairy cows fed increased energy from fat or concentrate. J. Dairy Sci. $79: 1836-1849$.

Grummer, R. R., and D. J. Carroll. 1991. Effects of dietary fat on metabolic disorders and reproductive performance of dairy cattle. J. Anim. Sci. 69:3838-3852.

Hammon, H. M., C. C. Metges, P. Junghans, F. Becker, O. Bellmann, F. Schnieder, G. Nürnberg, P. Dubreuil, and H. Lapierre. 2008. Metabolic changes and net portal flux in dairy cows fed a ration containing rumen-protected fat as compared to a control diet. J. Dairy Sci. 91:208-217.

Hanigan, M. D., J. France, D. Wray-Cahen, D. E. Beever, G. E. Lobley, L. Reutzel, and N. E. Smith. 1998. Alternative models for analyses of liver and mammary transorgan metabolite extraction data. Br. J. Nutr. 79:63-78.

Haque, M. N., J. Guinard-Flament, P. Lamberton, C. Mustière, and S. Lemosquet. 2015. Changes in mammary metabolism in response to the provision of an ideal amino acid profile at 2 levels of metabolizable protein supply in dairy cows: Consequences on efficiency. J. Dairy Sci. 98:3951-3968.

ISO (International Organization for Standardization). 2013. Milk and liquid milk products. Guidelines for the application of mid-infrared spectrometry. ISO, Geneva, Switzerland. 
Lapierre, H., R. Berthiaume, G. Raggio, M. C. Thivierge, L. Doepel, D. Pacheco, P. Dubreuil, and G. E. Lobley. 2005. The route of absorbed nitrogen into milk protein. Anim. Sci. 80:11-22.

Lapierre, H., C. E. Galindo, S. Lemosquet, I. Ortigues-Marty, L. Doepel, and D. R. Ouellet. 2010. Protein supply, glucose kinetics and milk yield in dairy cows. Pages $275-285$ in EAAP Publication No. 127. Wageningen Academic Publishers, Wageningen, the Netherlands.

Lapierre, H., G. E. Lobley, L. Doepel, G. Raggio, H. Rulquin, and S. Lemosquet. 2012. Mammary metabolism of amino acids in dairy cows. J. Anim. Sci. 90:1708-1721.

Larsen, M., C. Galindo, D. R. Ouellet, G. Maxin, N. B. Kristensen, and H. Lapierre. 2015. Abomasal amino acid infusion in postpartum dairy cows: Effect on whole-body, splanchnic, and mammary amino acid metabolism. J. Dairy Sci. 98:7944-7961.

Larsen, M., H. Lapierre, and N. B. Kristensen. 2014. Abomasal protein infusion in postpartum transition dairy cows: Effect on performance and mammary metabolism. J. Dairy Sci. 97:5608-5622.

Lemosquet, S., G. Raggio, G. E. Lobley, H. Rulquin, J. Guinard-Flament, and H. Lapierre. 2009a. Whole-body glucose metabolism and mammary energetic nutrient metabolism in lactating dairy cows receiving digestive infusions of casein and propionic acid. J. Dairy Sci. 92:6068-6082.

Lemosquet, S., E. Delamaire, H. Lapierre, J. W. Blum, and J. L. Peyraud. 2009b. Effects of glucose, propionic acid, and nonessential amino acids on glucose metabolism and milk yield in Holstein dairy cows. J. Dairy Sci. 92:3244-3257.

Linzell, J. L. 1974. Mammary blood flow and methods of identifying and measuring precursors of milk. Pages 143-225 in Lactation. Vol. 1. B. L. Larson and V. R. Smith, ed. Academic Press, New York, NY.

Lobley, G. E., and H. Lapierre. 2003. Post-absorptive metabolism of amino acids. Pages 737-753 in Progress in Research on Energy and Protein Metabolism. EAAP Publication No. 109. W. B. Souffrant and C. C. Metges, ed. Wageningen Academic Publishers, Wageningen, the Netherlands.

Lohrenz, A.-K., K. Duske, F. Schneider, K. Nürnberg, B. Losand, H. M. Seyfert, C. C. Metges, and H. Hammon. 2010. Milk performance and glucose metabolism in dairy cows fed rumen-protected fat during mid lactation. J. Dairy Sci. 93:5867-5876.

Mepham, T. B. 1987. Physiology of Lactation. Open University Press, Milton Keynes, UK.

Miller, P. S., B. L. Reis, C. C. Calvert, E. J. DePeters, and R. L. Baldwin. 1991. Patterns of nutrient uptake by the mammary glands of lactating dairy cows. J. Dairy Sci. 74:3791-3799.

Nichols, K., A. Bannink, S. Pacheco, H. J. van Valenberg, J. Dijkstra, and H. van Laar. 2018. Feed and nitrogen efficiency are affected differently but milk lactose production is stimulated equally when isoenergetic protein and fat is supplemented in lactating dairy cow diets. J. Dairy Sci. 101:7857-7870.

Nichols, K., J. Dijkstra, H. van Laar, S. Pacheco, H. J. van Valenberg, and A. Bannink. 2019. Energy and nitrogen partitioning in dairy cows at low or high metabolizable protein levels is affected differently by post-rumen glucogenic and lipogenic substrates. J. Dairy Sci. 102:395-412.
Nichols, K., J. Doelman, J. J. M. Kim, M. Carson, J. A. Metcalf, and J. P. Cant. 2017. Exogenous essential amino acids stimulate an adaptive unfolded protein response in the mammary glands of lactating cows. J. Dairy Sci. 100:5909-5921.

Nichols, K., J. J. M. Kim, M. Carson, J. A. Metcalf, J. P. Cant, and J. Doelman. 2016. Glucose supplementation stimulates peripheral branched-chain amino acid catabolism in lactating dairy cows during essential amino acid infusions. J. Dairy Sci. 99:1145-1160.

Nielsen, M. O., T. G. Madsen, and A. M. Hedeboe. 2001. Regulation of mammary glucose uptake in goats: Role of mammary gland supply insulin, IGF-1 and synthetic capacity. J. Dairy Res. 68:337-349.

Ørskov, E. R., D. E. Meehan, N. A. MacLeod, and D. J. Kyle. 1999. Effect of glucose supply on fasting nitrogen excretion and effect of level and type of volatile fatty acid infusion on response to protein infusion in cattle. Br. J. Nutr. 81:389-393.

Qiao, F., D. R. Trout, C. Xiao, and J. P. Cant. 2005. Kinetics of glucose transport and sequestrations in lactating bovine mammary glands measured in vivo with a paired indicator/nutrient dilution technique. J. Appl. Physiol. 99:799-806.

Raggio, G., S. Lemosquet, G. E. Lobley, H. Rulquin, and H. Lapierre. 2006. Effect of casein and propionate supply on mammary protein metabolism in lactating dairy cows. J. Dairy Sci. 89:4340-4351.

Raggio, G., D. Pacheco, R. Berthiaume, G. E. Lobley, D. Pellerin, G. Allard, P. Dubreuil, and H. Lapierre. 2004. Effect of level of metabolizable protein on splanchnic flux of amino acids in lactating dairy cows. J. Dairy Sci. 87:3461-3472.

Rigout, S., S. Lemosquet, A. Bach, J. W. Blum, and H. Rulquin. 2002. Duodenal infusion of glucose decreases milk fat production in grass silage-fed dairy cows. J. Dairy Sci. 85:2541-2550.

Rius, A. G., J. A. D. R. N. Appuhamy, J. Cyriac, D. Kirovski, O. Becvar, J. Escobar, M. L. McGilliard, B. J. Bequette, R. M. Akers, and M. D. Hanigan. 2010b. Regulation of protein synthesis in mammary glands of lactating dairy cows by starch and amino acids. J. Dairy Sci. 93:3114-3127.

Rius, A. G., M. L. McGilliard, C. A. Umberger, and M. D. Hanigan. 2010a. Interactions of energy and predicted metabolizable protein in determining nitrogen efficiency in the lactating dairy cow. J. Dairy Sci. 93:2034-2043.

Smith, G. H., B. Crabtree, and R. Smith. 1983. Energy metabolism in the mammary gland. Pages 121-141 in Biochemistry of Lactation. T. B. Mepham, ed. Elsevier, Amsterdam, the Netherlands.

van Hoeij, R. J., J. Dijkstra, R. M. Bruckmaier, J. J. Gross, T. J. G. M. Lam, G. J. Remmelink, B. Kemp, and A. T. M. van Knegsel. 2017. Consequences of dietary energy source and energy level on energy balance, lactogenic hormones, and lactation curve characteristics of cows after a short or omitted dry period. J. Dairy Sci. 100:8544-8564.

Weekes, T. L., P. H. Luimes, and J. P. Cant. 2006. Responses to amino acid imbalances and deficiencies in lactating dairy cows. J. Dairy Sci. 89:2177-2187.

Xiao, C. T., and J. P. Cant. 2005. Relationship between glucose transport and metabolism in isolated bovine mammary epithelial cells. J. Dairy Sci. 88:2794-2805. 